\title{
Processes controlling the annual cycle of Arctic aerosol number and size distributions
}

\author{
Betty Croft ${ }^{1}$, Randall V. Martin ${ }^{1,2}$, W. Richard Leaitch ${ }^{3}$, Peter Tunved ${ }^{4}$, Thomas J. Breider ${ }^{5}$, Stephen D. D’Andrea ${ }^{6}$, \\ and Jeffrey R. Pierce ${ }^{6,1}$ \\ ${ }^{1}$ Department of Physics and Atmospheric Science, Dalhousie University, Halifax, NS, Canada \\ ${ }^{2}$ Harvard-Smithsonian Center for Astrophysics, Cambridge, MA, USA \\ ${ }^{3}$ Climate Research Directorate, Environment and Climate Change Canada, Toronto, Ontario, Canada \\ ${ }^{4}$ Department of Environmental Science and Analytical Chemistry, Stockholm University, Stockholm, Sweden \\ ${ }^{5}$ School of Engineering and Applied Sciences, Harvard University, Cambridge, MA, USA \\ ${ }^{6}$ Department of Atmospheric Science, Colorado State University, Fort Collins, CO, USA
}

Correspondence to: Betty Croft (betty.croft@dal.ca)

Received: 2 October 2015 - Published in Atmos. Chem. Phys. Discuss.: 27 October 2015

Revised: 23 February 2016 - Accepted: 8 March 2016 - Published: 21 March 2016

\begin{abstract}
Measurements at high-Arctic sites (Alert, Nunavut, and Mt. Zeppelin, Svalbard) during the years 2011 to 2013 show a strong and similar annual cycle in aerosol number and size distributions. Each year at both sites, the number of aerosols with diameters larger than $20 \mathrm{~nm}$ exhibits a minimum in October and two maxima, one in spring associated with a dominant accumulation mode (particles 100 to $500 \mathrm{~nm}$ in diameter) and a second in summer associated with a dominant Aitken mode (particles 20 to $100 \mathrm{~nm}$ in diameter). Seasonal-mean aerosol effective diameter from measurements ranges from about 180 in summer to $260 \mathrm{~nm}$ in winter. This study interprets these annual cycles with the GEOS-Chem-TOMAS global aerosol microphysics model. Important roles are documented for several processes (new-particle formation, coagulation scavenging in clouds, scavenging by precipitation, and transport) in controlling the annual cycle in Arctic aerosol number and size.

Our simulations suggest that coagulation scavenging of interstitial aerosols in clouds by aerosols that have activated to form cloud droplets strongly limits the total number of particles with diameters less than $200 \mathrm{~nm}$ throughout the year. We find that the minimum in total particle number in October can be explained by diminishing new-particle formation within the Arctic, limited transport of pollution from lower latitudes, and efficient wet removal. Our simulations indicate that the summertime-dominant Aitken mode is associated with efficient wet removal of accumulation-mode aerosols,
\end{abstract}

which limits the condensation sink for condensable vapours. This in turn promotes new-particle formation and growth. The dominant accumulation mode during spring is associated with build up of transported pollution from outside the Arctic coupled with less-efficient wet-removal processes at colder temperatures. We recommend further attention to the key processes of new-particle formation, interstitial coagulation, and wet removal and their delicate interactions and balance in size-resolved aerosol simulations of the Arctic to reduce uncertainties in estimates of aerosol radiative effects on the Arctic climate.

\section{Introduction}

The climate impact of aerosols strongly depends on aerosol number and size distributions (Haywood and Boucher, 2000; Lohmann and Feichter, 2005). These aerosol properties, in addition to chemical composition, contribute to aerosol effects on the Earth's climate. Aerosols influence the global climate directly through scattering and absorption of radiation (Charlson et al., 1992) and indirectly by modifying cloud properties (Twomey, 1974; Albrecht, 1989). Aerosols play an important role in the Arctic climate, and changing aerosol concentrations are believed to have contributed to the rapid Arctic warming observed over the past few decades (Shindell and Faluvegi, 2009). However, in the Arctic there are 
complex aerosol feedbacks and strong seasonal aerosol cycles that make study of aerosol-climate interactions particularly challenging in this remote region (Browse et al., 2012, 2014). To address a portion of this challenging puzzle, this study focuses on understanding the processes that control the Arctic aerosol number and size distributions over the entire annual cycle.

Observations at Arctic sites show a strong and similar annual cycle in aerosol number and size distributions (e.g. Ström et al., 2003; Leaitch et al., 2013; Tunved et al., 2013). In the high Arctic, at Mt. Zeppelin, Svalbard, and Alert, Nunavut, Canada, the observed annual cycle in aerosol number exhibits two maxima: one in MarchApril associated with dominance of accumulation-mode particles and one in July associated with smaller, Aitken-mode particles. The inter-seasonal transition from accumulationmode-dominated springtime distributions to Aitken-modedominated summertime distributions has been observed not only at surface sites but also in the free troposphere (Engvall et al., 2008). This inter-seasonal transition from spring to summer has been extensively studied; evidence suggests control by changes in aerosol wet-removal efficiency, newparticle formation, and transport patterns (e.g. Korhonen et al., 2008; Garrett et al., 2010; Sharma et al., 2013). Moreefficient wet removal in the midlatitudes and within the Arctic in late spring and summer inhibits transport of aged accumulation-mode aerosols into the Arctic. These summertime conditions favour new-particle formation (hereafter referred to as NPF) from precursor vapours within the Arctic boundary layer due to the low condensation sink for particleprecursor vapours on to existing aerosol surface area, and the low coagulation sink for newly formed, growing particles (Leaitch et al., 2013; Heintzenberg et al., 2015).

Korhonen et al. (2008) conducted a pioneering global aerosol model study to interpret the processes controlling the spring-to-summer transition in Arctic aerosol number and size observed from Svalbard and the shipboard campaigns of Heintzenberg et al. (2006). The focus of that study was limited to spring-summer and the transition between these seasons. In our study, we extend the temporal scope to consider the entire annual cycle and use observations from both Svalbard and Nunavut, about $1000 \mathrm{~km}$ apart. Over recent years, numerous studies have focused on the spring-summer transitions in aerosol mass abundance using observations and models to examine the role of transport and scavenging (Garrett et al., 2010, 2011; Browse et al., 2012; Di Pierro et al., 2013; Sharma et al., 2013; Stohl et al., 2013). However, there has been considerably less focus on Arctic aerosol number and size distributions. To our knowledge, ours is the first global modelling study to consider the complete annual cycle in Arctic aerosol number and size.

In this study, we examine aerosol number and size distributions over recent years (2011-2013) at the Canadian high-Arctic measurement site at Alert, Nunavut $\left(82.5^{\circ} \mathrm{N}\right)$, and the European site at Mt. Zeppelin, Svalbard $\left(79^{\circ} \mathrm{N}\right)$. We use the GEOS-Chem global chemical transport model (Bey et al., 2001; www.geos-chem.org) with the size-resolved aerosol microphysics package TOMAS (D'Andrea et al., 2013; Pierce et al., 2013; Trivitayanurak et al., 2008) to examine the relative importance of various aerosol processes (NPF, emissions, removal, and microphysical processes such as condensation and coagulation) in controlling the annual cycle of aerosol number and size distribution in the Arctic.

While the importance of wet removal is well known (Korhonen et al., 2008; Garrett et al., 2010; Browse et al., 2012), relatively less attention has been given to coagulation of interstitial particles in clouds, which is another sink process for aerosol number. We implemented a mechanism in GEOSChem-TOMAS that represents coagulation between aerosols that have activated to form cloud droplets and interstitial aerosols (defined as particles within clouds but outside of cloud droplets). This mechanism accounts for the $\sim 100$ fold increase in size (due to water uptake) for particles that are cloud condensation nuclei and have activated to form cloud droplets. This size change increases the coagulation rate of smaller Aitken-mode aerosols with these larger activated aerosols. Pierce et al. (2015) showed that the inclusion of this mechanism to GEOS-Chem-TOMAS brings aerosol size distributions to closer agreement with observations globally. Cesana et al. (2012) analysed CALIOP retrievals using the cloud-phase detection algorithm and found that low-level liquid clouds are ubiquitous in all seasons in the Arctic. Thus, this in-cloud coagulation process is particularly relevant for the Arctic.

The following section describes the 2011-2013 highArctic measurements and gives an overview of the GEOSChem-TOMAS simulations conducted for this study. Section 3 examines the monthly and seasonal-mean in situ observations of aerosol number and size from scanning mobility particle sizer (SMPS) at Alert and differential mobility particle sizer (DMPS) at Mt. Zeppelin. The GEOS-ChemTOMAS model is used to interpret the annual cycle of these measurements. We subsequently present the process rates that control the aerosol annual cycles in our simulations.

\section{Method}

\subsection{Measurements at Alert}

Measurements of particle size distributions at Alert have been ongoing since March 2011 with the exception of a few technical interruptions. Sampling of the ambient aerosol size distribution at Alert was conducted as described by Leaitch et al. (2013). Briefly, the particles are sampled through stainless steel tubing with a mean residence time for a particle from outside to its measurement point of approximately $3 \mathrm{~s}$. At the point of sampling, the aerosol is at a temperature $(T)$ of approximately $293 \mathrm{~K}$ and the relative humidity (RH) is $<50 \%$. The total number concentration of particles larger 
than $10 \mathrm{~nm}$ in diameter at Alert is measured with a TSI 3772 condensation particle counter (CPC) operating at a flow rate of $1 \mathrm{~L} \mathrm{~min}^{-1}$. The size distributions for particles from 20 to $500 \mathrm{~nm}$ in diameter are measured with a TSI 3034 SMPS, operating at a flow rate of $1 \mathrm{~L} \mathrm{~min}^{-1}$ and verified for sizing on site using mono-disperse particles of polystyrene latex and of ammonium sulfate generated with a Brechtel Manufacturing Incorporated scanning electrical mobility spectrometer and for number concentrations through comparison with the TSI 3772 CPC. The Alert SMPS data are accurate to within $15 \%$ in terms of number concentration and sizing. The TSI 3772 CPC was initially compared with a TSI 3775 CPC temporarily operating at the site and measuring the number of particles with sizes larger than $4 \mathrm{~nm}$. The differences between the TSI 3772 and 3775 CPC were found to be $<10 \%$ when there was no evidence of particles smaller than $10 \mathrm{~nm}$. The TSI 3772 CPC also compares to within $10 \%$ with the SMPS when particle sizes are large enough for all particles to be counted by both instruments (e.g. during periods of Arctic Haze).

\subsection{Measurements at Mt. Zeppelin}

The Department of Environmental Science and Analytical Chemistry, Section for Atmospheric research (ACES), Stockholm University (SU), has monitored the sub-micron aerosol number size distribution at Mt. Zeppelin since 2000 with a DMPS. Today, this more-than-15-year continuous data set constitutes one of the longest unbroken aerosol number size distribution observation series in the Arctic.

During the 15 years of operation, the DMPS system has undergone a number of modernizations. Initially a single differential mobility analyzer (DMA) system was used covering a size range between roughly 20 and $600 \mathrm{~nm}$. A major overhaul was performed during late 2010 , and since then the set-up has remained unchanged, covering a size range of 5$800 \mathrm{~nm}$. Thus, the data used in our study (2011-2013) come from the same instrument configuration.

This DMPS system utilizes a custom-built twin DMA setup comprising one Vienna-type medium DMA coupled to a TSI CPC 3772 covering sizes between $25-800 \mathrm{~nm}$ and a Vienna-type long DMA coupled with at TSI CPC 3772 effectively covering sizes between 5 and $60 \mathrm{~nm}$. The size distributions from the two systems are harmonized on a common size grid and then merged. Both systems use a closed-loop set-up. The inlet hat is a whole air inlet according to EUSAAR standard. In the current set-up, the inlet operates with a flow rate of about $100 \mathrm{~L} \mathrm{~min}^{-1}$ and consists of several stainless steel tubes. The $25 \mathrm{~mm}$ diameter DMPS sampling tube is in total $4.5 \mathrm{~m}$ long. Inside the station, the flow is split into progressively smaller tubing until reaching $1 \mathrm{~L} \mathrm{~min}^{-1}$ at the DMPS. Laminar flow condition applies throughout the sampling line. On the outside, the inlet temperature is kept above $273 \mathrm{~K}$ using active heating. Inside the station the temperature increases gradually to room temperature (maximum temper- ature of $298 \mathrm{~K}$, but typically around $293 \mathrm{~K}$ ). RH and $T$ are internally monitored and measurements are at dry conditions with $\mathrm{RH}<30 \%$. The system is regularly checked with latex spheres and flow controls. The data are manually screened and crosschecked with other available observations.

\subsection{GEOS-Chem-TOMAS model description}

In this study, we use the GEOS-Chem-TOMAS model, which couples the GEOS-Chem global chemical transport model (www.geos-chem.org; Bey et al., 2001) with the TwOMoment Aerosol Sectional (TOMAS) microphysics scheme (Adams and Seinfeld, 2002; Lee and Adams, 2012). All simulations use GEOS-Chem version 9.02 at $4^{\circ} \times 5^{\circ}$ resolution globally, corresponding to $440 \mathrm{~km} \times 95 \mathrm{~km}$ at $80^{\circ} \mathrm{N}$. The model has 47 layers extending from the surface to $0.01 \mathrm{hPa}$. Simulations at Mt. Zeppelin are sampled at the station altitude of $500 \mathrm{~m}$. Assimilated meteorology is from the National Aeronautics and Space Administration (NASA) Global Modelling and Assimilation Office (GMAO) Goddard Earth Observing System version 5 (GEOS-5). All simulations use meteorology and emissions for the year 2011 following 3 months spin-up at the end of 2010. GEOS-Chem includes simulation of more than 50 gas-phase species including oxidants such as $\mathrm{OH}$ and aerosol-precursor gases such as $\mathrm{SO}_{2}$ and $\mathrm{NH}_{3}$. Emissions in GEOS-Chem-TOMAS are described in Stevens and Pierce (2014). In addition, we implement seabird-colony $\mathrm{NH}_{3}$ emissions from Riddick et al. (2012) with modifications for additional colonies in the Arctic region based on the online Circumpolar Seabird Data Portal (Seabird Information Network, 2015) as described and evaluated in Wentworth et al. (2016). Our simulations include secondary organic aerosol, both biogenic $\left(\sim 19 \mathrm{Tg} \mathrm{yr}^{-1}\right)$ and enhanced anthropogenic non-volatile (100 $\mathrm{Tg} \mathrm{yr}^{-1}$ ) spatially correlated with anthropogenic CO emissions (D'Andrea et al., 2013).

The TOMAS microphysics scheme tracks the number and mass of particles within each of 15 dry size sections. The first 13 size sections are logarithmically spaced, including aerosol dry diameters from approximately $3 \mathrm{~nm}$ to $1 \mu \mathrm{m}$, while 2 additional size sections represent aerosol dry diameters from 1 to $10 \mu \mathrm{m}$ (Lee and Adams, 2012). Simulated aerosol species are sulfate, sea spray, hydrophilic organics, hydrophobic organics, internally mixed black carbon, externally mixed black carbon, dust, and water. Aerosol hygroscopic growth is a function of grid-box mean RH capped at $99 \%$. Simulated aerosols are treated as dry $(\mathrm{RH}=0 \%)$ for comparison with the measurements presented in this study

For these simulations, NPF is treated according to the state-of-the-science ternary $\mathrm{H}_{2} \mathrm{SO}_{4}-\mathrm{NH}_{3}-\mathrm{H}_{2} \mathrm{O}$ nucleation scheme described by Baranizadeh et al. (2016). The formation rate of particles at ca. $1.2 \mathrm{~nm}$ in mass diameter is determined from a full kinetics simulation by Atmospheric Cluster Dynamics Code (ACDC; Olenius et al., 2013) using particle evaporation rates based on quantum chemistry. 
The scheme is implemented as a comprehensive look-up table of simulated formation rates as a function of sulfuric acid and ammonia vapour concentrations, relative humidity, temperature, and condensation sink for condensable vapours (existing aerosol surface area). Growth and loss of particles with diameters smaller than $3 \mathrm{~nm}$ are approximated with the Kerminen et al. (2004) scheme (evaluated in TOMAS in Y. H. Lee et al., 2013). In our simulations, we do not include NPF by organic vapours such as those arising from the oceans (O'Dowd and de Leeuw, 2007; Fu et al., 2013). Currently, no single nucleation scheme includes contributions from organics, sulfuric acid, bases, and water. As well, Giamarelou et al. (2016) found that nucleation-mode particles in the Arctic are predominantly ammonium sulfates.

Growth of simulated particles occurs by condensation of sulfuric acid and organic vapours, which we assume to be non-volatile. These vapours condense proportional to the Fuchs-corrected aerosol surface area distribution (Donahue et al., 2011; Pierce et al., 2011; Riipinen et al., 2011). Condensational growth is not a sink for aerosol number but does transfer aerosol number between size bins while increasing aerosol mass. Coagulation is an important sink for aerosol number (particularly for aerosols with diameters smaller than $100 \mathrm{~nm}$ ) and moves aerosol mass to larger sizes. Our simulations use the Brownian coagulation scheme of Fuchs (1964) and consider coagulation between all particle sizes.

In our simulations, aerosols are removed from the atmosphere by precipitation both in and below clouds (Liu et al., 2001) as well as by dry deposition using a resistance in-series approach (Wesley, 1989) assuming an aerosol dry deposition velocity of $0.03 \mathrm{~cm} \mathrm{~s}^{-1}$ over snow and ice. Wet deposition is an important sink process for aerosols larger than about 50$100 \mathrm{~nm}$ in diameter. The in-cloud wet scavenging parameterization in the standard GEOS-Chem-TOMAS module uses the same equations for the removal efficiency and the precipitation fraction as in the bulk-aerosol GEOS-Chem module described in Liu et al. (2001) with updates implemented by Wang et al. (2011) to account for wet removal in mixed-phase and ice clouds. The aerosol in-cloud wet removal in GEOSChem-TOMAS is limited to the aerosol size range that is assumed activated into cloud hydrometeors.

\subsection{Simulations and revisions to model parameterizations}

Table 1 summarizes the four simulations conducted with the GEOS-Chem-TOMAS model. These simulations include (1) a standard, (2) updates to wet removal, (3) updates that add the process of interstitial coagulation of aerosols in clouds, and (4) a sensitivity test with no NPF. The first (simulation STD) uses the standard GEOS-Chem-TOMAS model as described above.

Simulation NEWSCAV introduces developments to the wet-removal parameterization to allow for variable in-cloud water content, to implement a temperature-dependent aerosol activation fraction, and to more closely relate in-cloud aerosol scavenging to cloud fraction. The standard GEOSChem-TOMAS wet-removal efficiency $\beta$ for large-scale clouds is based on a parameterization originally developed by Giorgi and Chameides (1986):

$\beta=k_{\min }+Q / L$,

where $Q$ is the grid-box mean precipitation production rate $\left(\mathrm{g} \mathrm{cm}^{-3} \mathrm{~s}^{-1}\right)$ from the GEOS-5 meteorological fields, $L$ is the in-cloud liquid and ice water content $\left(\mathrm{g} \mathrm{cm}^{-3}\right)$ of the precipitating clouds (an assumed constant), and $k_{\min }$ is a constant, $1 \times 10^{-4} \mathrm{~s}^{-1}$. The $k_{\min }$ term represents autoconversion processes that produce precipitation. The $Q / L$ term represents accretion processes. The standard GEOS-Chem model uses a globally fixed value for $L$ of $1 \times 10^{-6} \mathrm{~g} \mathrm{~cm}^{-3}$. While this value performs well for wet scavenging in a global sense (Liu et al., 2001; Wang et al., 2011), the value does not represent observations well in certain regions. Measurements by Shupe et al. (2001) and Leaitch et al. (2016) show an Arctic spring-summer mean cloud liquid water content that is an order of magnitude lower $\left(1 \times 10^{-7} \mathrm{~g} \mathrm{~cm}^{-3}\right)$. During the spring and summer, more efficient aerosol removal in liquid clouds plays a key role in the control of aerosol distributions (Garrett et al., 2010). An overestimation of the liquid water content of Arctic clouds (by using a globally fixed value for $L$ ) in our simulation would yield under-vigorous wet-removal efficiency, particularly for cases of low-intensity precipitation (low $Q$ ). To address this issue, we replace the fixed value with the cloud liquid and ice water contents from the GEOS5 assimilated meteorology fields and calculate the efficiency as the ratio of the grid-mean precipitation production rate and the grid-mean liquid and ice water contents. We impose a maximum efficiency $\left(1 \times 10^{-3} \mathrm{~s}^{-1}\right)$ to prevent over-vigorous removal. This value is consistent with the upper limit for these process rates given in Gettelman et al. (2013).

In addition, we implement a temperature-dependent representation of the aerosol activated fraction (Verheggen et al., 2007) to account for the fraction of aerosol susceptible to wet removal in mixed-phase clouds. In mixed-phase clouds, only a fraction of the aerosols are contained in the cloud hydrometeors and susceptible to removal when cloud water and ice converts to precipitation. As clouds glaciate, cloud droplets evaporate and release aerosols from the condensed phase because ice crystals grow at the expense of cloud droplets due to differences in the saturation vapour pressure over liquid water and ice. The Verheggen et al. (2007) parameterization for activated fraction accounts for this effect, such that only a fraction of the total in-cloud aerosol is susceptible to wet removal as precipitation forms in mixed-phase clouds. However, in strongly riming-dominated regimes, this may lead to an underestimation of the removal.

We also develop the representation of the precipitation fraction. In the standard GEOS-Chem model, the fraction of the grid box that is precipitating, $F$, is 
Table 1. Summary of the simulations conducted for this study.

\begin{tabular}{llll}
\hline Simulation name & Revised wet removal & With interstitial coagulation & With new-particle formation \\
\hline STD & no & no & yes \\
NEWSCAV & yes & no & yes \\
NEWSCAV+COAG & yes & yes & yes \\
NONUC & yes & no & no \\
\hline
\end{tabular}

$F=Q / \beta L$

Replacing $\beta$ with Eq. (1) and simplifying yields

$F=1 /\left(1+\left(k_{\min } L / Q\right)\right)$,

where $k_{\min } L$ has a fixed value of $1 \times 10^{-10} \mathrm{~g} \mathrm{~cm}^{-3} \mathrm{~s}^{-1}$ in the standard model version. Thus, the precipitation fraction increases with precipitation production rate. We replace this parameterization by treating the precipitation fraction for aerosol scavenging in clouds as the cloud fraction from the GEOS-5 meteorological fields in the model layers where precipitation is produced. These wet scavenging developments were also implemented in a GEOS-Chem v9-03-01 simulation of ${ }^{137} \mathrm{Cs}$ (also using GEOS5 met fields) and evaluated against ${ }^{137} \mathrm{Cs}$ measurements taken for several weeks following the March 2011 Fukushima Daiichi nuclear power plant accident. Implementation of these scavenging revisions yielded improved agreement with the radionuclide measurements (median ratio of measured to modelled surface-layer concentrations changed from 5.53 to 0.52 ) and reduced efolding times from 21.8 to 13.2 days, which is close to the measurement value of 14.3 days (Kristiansen et al., 2016). These wet-removal revisions also slightly reduced the mean bias relative to measurements of the number of aerosols larger than $40 \mathrm{~nm}(\mathrm{~N} 40), 80 \mathrm{~nm}(\mathrm{~N} 80)$, and $150 \mathrm{~nm}$ (N150) for the same global set of 21 geographically diverse sites as described in D'Andrea et al. (2013) (not shown).

Simulation NEWSCAV+COAG includes additional developments to the interstitial aerosol coagulation mechanism in clouds for the TOMAS microphysics scheme as explored in Pierce et al. (2015). This revised coagulation parameterization accounts for the order 100-fold increase in the wet size of aerosols that activate to form cloud droplets. This simulation assumes for the purposes of coagulation only that (1) aerosols that activate to form cloud droplets must have a dry diameter larger than $80 \mathrm{~nm}$, (2) super-cooled clouds persist to temperatures as low as $238 \mathrm{~K}$, and (3) all cloud droplets are $10 \mu \mathrm{m}$ in diameter. While these are crude assumptions, they are within reasonable bounds and allow examination of the potential of interstitial coagulation to control aerosol size distributions. The grid-box mean coagulation kernel between two size bins is calculated as

$$
\begin{aligned}
J_{i, j} & =\left(1-f_{\text {cloudy }}\right) K_{\text {clear } ; i, j}, N_{i} N_{j} \\
& +f_{\text {cloudy }} K_{\text {cloudy } ; i, j} N_{i} N_{j},
\end{aligned}
$$

where $J_{i, j}$ is the coagulation rate between particles in bins $i$ and $j, f_{\text {cloudy }}$ is the fraction of the grid box that is cloudy, $K_{\text {clear;i,j }}$ is the coagulation kernel between bins $i$ and $j$ in the clear portion of the grid box, $K_{\text {cloudy;i,j }}$ is the coagulation kernel between bins $i$ and $j$ in the cloudy portion of the grid box, $N_{i}$ is the number concentration of particles in bin $i$, and $N_{j}$ is the number concentration of particles in bin $j$. While the activated particle is treated as having a diameter of $10 \mu \mathrm{m}$, the unactivated collision-partner aerosol is treated as having a diameter following hygroscopic growth under gridbox mean relative humidity. If the in-cloud relative humidity is considerably greater than the grid mean, then the coagulation kernel could be overestimated. These developments to the interstitial aerosol coagulation parameterization in clouds are applied and evaluated in Pierce et al. (2015) and yielded improved agreement with in situ aerosol size distributions at 21 geographically diverse sites in the Northern Hemisphere.

Simulation NONUC turns off NPF globally to examine the contribution of NPF to aerosol number in the Arctic. This simulation is otherwise identical to simulation NEWSCAV.

\section{Observations and GEOS-Chem-TOMAS simulations of annual cycles in Arctic aerosol number and size}

\subsection{Observed annual cycle in Arctic aerosol number and size}

Figure 1 shows the 2011-2013 monthly median aerosol number distributions from the SMPS at Alert and DMPS at Mt. Zeppelin. At both sites, the accumulation mode (defined here as particles with diameters from 0.1 to $0.5 \mu \mathrm{m}$ due to instrument range, although typically extending to $1 \mu \mathrm{m}$ ) gradually builds during winter to a maximum in March and April. Afterward, the accumulation mode decreases while the Aitken mode (defined here as particles of 0.02 to $0.1 \mu \mathrm{m}$ in diameter due to instrument range, although typically extending to $0.01 \mu \mathrm{m}$ ) increases in number to a maximum in July-August. October is characterized by the lowest number concentrations in both modes until the accumulation mode starts to build again in November. As a result, the total aerosol number at both locations has a shallow maximum in both spring 


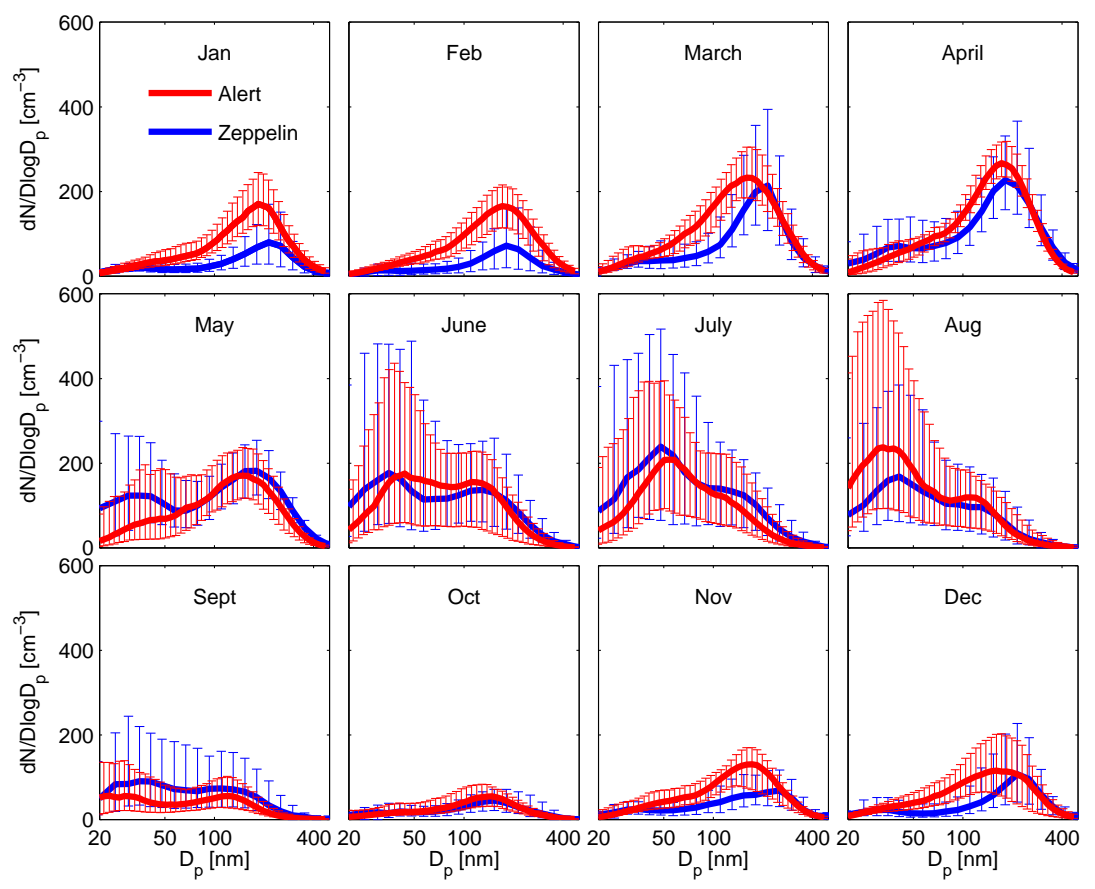

Figure 1. Measured monthly median number distributions from the scanning mobility particle sizer (SMPS) at Alert for 2011-2013 and the differential mobility particle sizer (DMPS) at Mt. Zeppelin for 2011-2013 for particle sizes between 20 and $500 \mathrm{~nm}$. Error bars show the 20-80th percentile of the measurements.

and summer. In Fig. 1, the magnitude between the 20th to 80th percentiles for particles smaller than $100 \mathrm{~nm}$ is greatest during the months of June to August when NPF processes in the Arctic boundary layer are expected to make strong and episodic contributions to the aerosol number (e.g. Korhonen et al., 2008; Leaitch et al., 2013). The complete annual cycle is remarkably similar at both sites and similar to that observed at Mt. Zeppelin over an earlier 10-year period from 2000 to 2010 (Fig. 7 in Tunved et al., 2013). The similarity in these number distributions across the $1000 \mathrm{~km}$ that separates Alert and Mt. Zeppelin suggests an annual cycle that spans the high Arctic. In the following sections we use the GEOS-Chem-TOMAS model to interpret the processes that control these cycles.

Figure 2 shows the monthly median aerosol effective diameter calculated from the 2011-2013 measurements with SMPS at Alert and DMPS at Mt. Zeppelin. The effective diameter is the ratio of the second and third moments of the aerosol number distribution and is useful for determining the optical properties of an aerosol distribution and for comparing between distributions. The effective diameter is defined as

$D_{\text {eff }}=\int_{D_{\min }}^{D_{\max }} D^{3} N(D) \mathrm{d} D / \int_{D_{\min }}^{D_{\max }} D^{2} N(D) \mathrm{d} D$,

where $D$ is the aerosol diameter and $N(D)$ is the aerosol number distribution. The integral here is taken over the in- strument size range from $D_{\min }=20 \mathrm{~nm}$ to $D_{\max }=500 \mathrm{~nm}$. Despite the geographic distance of these two sites, the annual cycle of the aerosol effective diameter is remarkably similar. At both sites, the aerosol effective diameter shows a strong annual cycle with a minimum during the summer months of about $180 \mathrm{~nm}$ and a maximum in the winter of about $260 \mathrm{~nm}$. The effective diameter at Mt. Zeppelin exceeds Alert by about 10-20\% throughout the year. In the next sections, we interpret these observed annual cycles in number and size using the GEOS-Chem-TOMAS model.

\subsection{Interpreting processes controlling the annual cycle of aerosol number and size with GEOS-Chem-TOMAS}

Figures 3 and 4 show the seasonal-median number distributions from measurements at Alert and Mt. Zeppelin respectively for winter (DJF), spring (MAM), summer (JJA), and autumn (SON) and also for our four simulations. The measurement distributions exhibit the key features of Arctic aerosol size distributions, a dominant Aitken mode in summer, a dominant accumulation mode with suppressed Aitken mode in non-summer seasons, and minimum number in autumn. To assist in interpreting Figs. 3 and 4, we calculate the fractional bias between the observed and simulated total number of aerosols over two size ranges available from the measurement data: (1) Aitken particles $20-100 \mathrm{~nm}$ in diameter and (2) accumulation particles $100-500 \mathrm{~nm}$ in diameter. 


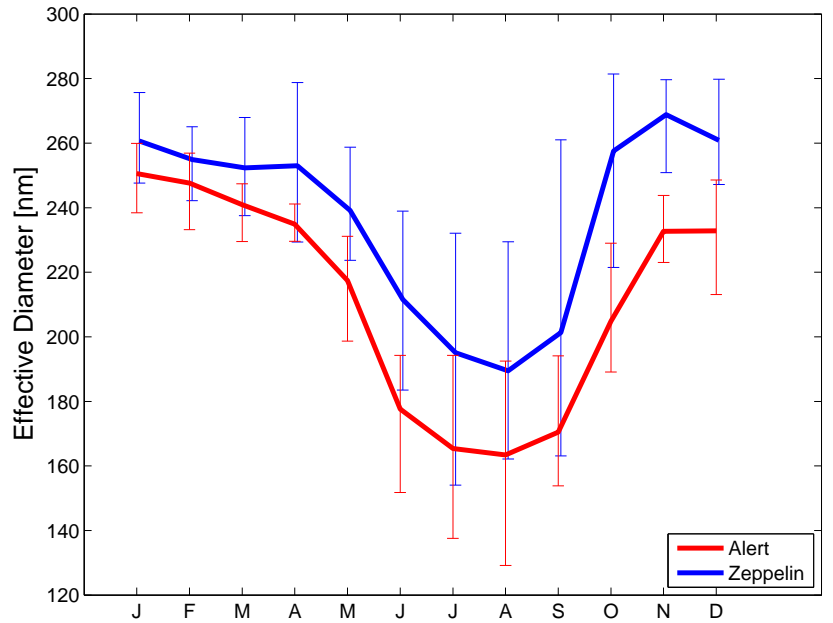

Figure 2. Measurement monthly median aerosol effective diameter from SMPS and DMPS at the two high-Arctic sites, Alert (20112013), and Mt. Zeppelin (2011-2013) respectively for particle sizes between 20 and $500 \mathrm{~nm}$. Error bars show the 20th and 80th percentiles.

We apply a size limit of 20-500 $\mathrm{nm}$ to the Mt. Zeppelin measurement data and to our simulations to be consistent with the available data from Alert. We define fractional bias (FB) as

$\mathrm{FB}=\left(C_{\mathrm{m}}-C_{0}\right) / C_{0}$,

where $C_{\mathrm{m}}$ is the model value and $C_{0}$ is the observed value. These seasonal fractional bias values are presented in Tables 2 and 3. Among all four simulations, simulation STD never has the fractional bias closest to zero for the size ranges considered in Tables 2 and 3.

The strong control of wet removal on Arctic aerosol number and size distributions throughout the annual cycle is highlighted by comparison of simulations STD and NEWSCAV in Figs. 3 and 4 and in Tables 2 and 3. For both Alert and Mt. Zeppelin, the standard GEOS-Chem-TOMAS model (simulation STD) overestimates the observed number of 100 $500 \mathrm{~nm}$ diameter particles in all seasons as quantified by the positive fractional bias values in Tables 2 and 3. At both Alert and Mt. Zeppelin, this bias is reduced in spring and summer for simulation NEWSCAV relative to STD. The bias reduction is greatest in summer when aerosol wet removal by precipitation is more efficient within the Arctic boundary layer, and it strongly limits the accumulation-mode number at the surface sites. The efficiency of wet removal is parameterized to increase with temperature (from 238 to $273 \mathrm{~K}$ ) in our simulations. In seasons other than summer, wet removal in the Arctic boundary layer is less efficient. However, wet removal outside the Arctic boundary layer continues to influence the number of accumulation-mode particles transported to the measurement sites. Over a limited size range (200$500 \mathrm{~nm}$ diameter particles) and in all seasons at both sites,
Table 2. Model-measurement fractional bias (Eq. 6) for total number of aerosols with diameters of 20-100 and 100-500 nm at Alert (in reference to Fig. 3). Bias values closest to zero for each season are highlighted in bold.

\begin{tabular}{lrrrr}
\hline Bias & STD & NEWSCAV & $\begin{array}{r}\text { NEWSCAV } \\
+ \text { COAG }\end{array}$ & NONUC \\
\hline 20-100 nm & & & & \\
\hline Winter & 1.95 & 3.45 & $\mathbf{0 . 1 8}$ & 1.47 \\
Spring & 0.83 & 1.12 & -0.46 & $-\mathbf{0 . 3 6}$ \\
Summer & -0.58 & 0.56 & $\mathbf{0 . 2 3}$ & -0.92 \\
Autumn & 0.15 & 3.53 & 0.52 & $\mathbf{0 . 0 7}$ \\
\hline 100-500 nm & & & & \\
\hline Winter & 0.66 & 0.87 & 0.40 & $\mathbf{0 . 3 4}$ \\
Spring & 0.38 & 0.30 & $-\mathbf{0 . 0 1}$ & -0.40 \\
Summer & 0.98 & 0.21 & $\mathbf{0 . 0 5}$ & -0.43 \\
Autumn & 0.40 & 1.34 & 0.78 & $\mathbf{0 . 0 1}$ \\
\hline
\end{tabular}

Table 3. Model-measurement fractional bias (Eq. 6) for total number of aerosols with diameters of $20-100$ and $100-500 \mathrm{~nm}$ at Mt. Zeppelin (in reference to Fig. 4). Bias values closest to zero for each season are highlighted in bold.

\begin{tabular}{lrrrr}
\hline Bias & STD & NEWSCAV & $\begin{array}{r}\text { NEWSCAV } \\
+ \text { COAG }\end{array}$ & NONUC \\
\hline 20-100 nm & & & & \\
\hline Winter & 6.73 & 12.87 & $\mathbf{3 . 1 7}$ & 5.43 \\
Spring & 0.68 & 1.01 & $-\mathbf{0 . 4 0}$ & -0.43 \\
Summer & -0.65 & $-\mathbf{0 . 2 1}$ & -0.54 & -0.90 \\
Autumn & 0.34 & 4.59 & 1.14 & $\mathbf{0 . 1 0}$ \\
\hline 100-500 nm & & & & \\
\hline Winter & 3.24 & 3.42 & 2.18 & $\mathbf{2 . 0 9}$ \\
Spring & 0.96 & 0.49 & $\mathbf{0 . 1 9}$ & -0.22 \\
Summer & 0.60 & $\mathbf{0 . 0 2}$ & -0.15 & -0.61 \\
Autumn & 1.50 & 1.63 & 0.99 & $\mathbf{0 . 1 2}$ \\
\hline
\end{tabular}

NEWSCAV is a closer match to measurements than STD, but the difference between STD and NEWSCAV is very small at Alert in winter and spring.

Wet removal also has feedbacks that particularly influence Aitken-mode and 100-200 nm diameter particle numbers indirectly through changes in NPF and subsequent particle growth to these sizes. Figures 3 and 4 show that at both sites and in all seasons, more vigorous wet removal in simulation NEWSCAV relative to STD yields more numerous Aitkenmode particles (although the springtime difference is very small) and, in autumn and winter, also more numerous 100 $200 \mathrm{~nm}$ particles. A reduction in surface area of $200-500 \mathrm{~nm}$ aerosols by more vigorous wet removal (simulation NEWSCAV relative to STD) promotes NPF and particle growth. Other than in summer, this NPF occurs primarily outside the Arctic boundary layer and growth occurs during transport to 

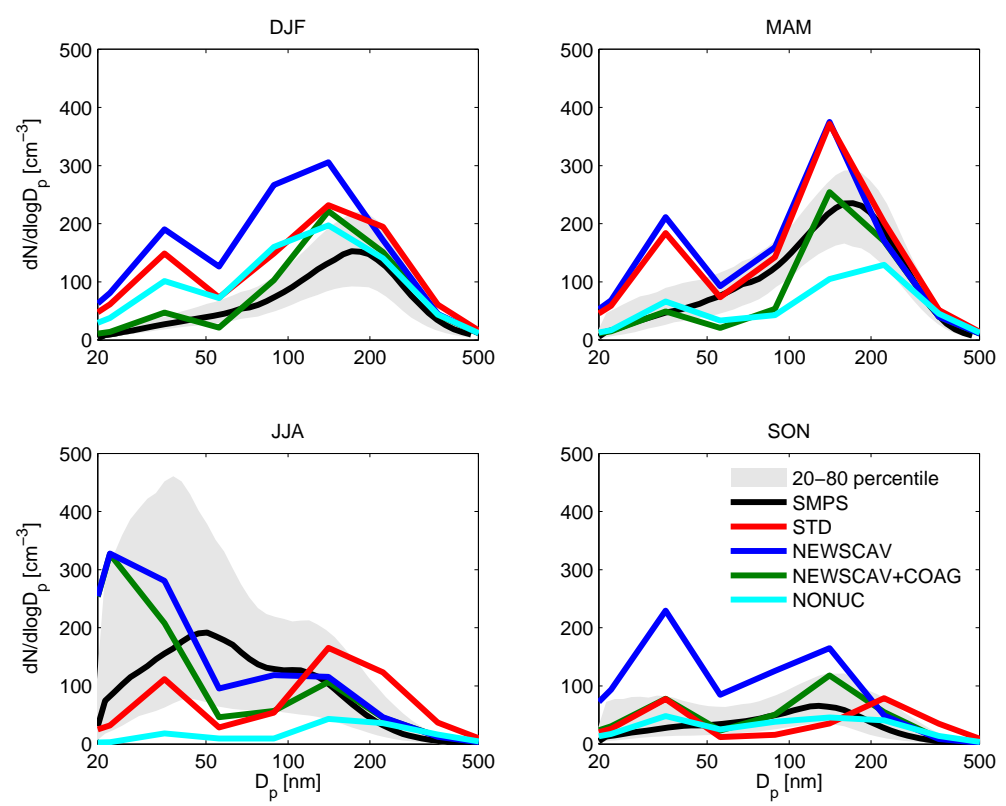

Figure 3. Seasonal-median number distributions from SMPS measurements at Alert (2011-2013) and for the GEOS-Chem-TOMAS dry size distribution simulations (described in Table 1). The measurement 20-80th percentile is in grey shading. Simulations are shown in colour as indicated by legend.

the measurement sites. As a result of the increase in number of 20-200 nm particles in simulation NEWSCAV relative to STD, the accumulation-mode bias is greater for NEWSCAV in autumn and winter at both sites and the Aitken-mode bias is greater for NEWSCAV in autumn, winter, and spring at both sites (Tables 2 and 3).

The balance of these processes of NPF, growth, and wet removal is a challenge for Arctic simulations of number and size. In all seasons at both sites (except for summer at Mt. Zeppelin), NEWSCAV strongly over estimates the number of $20-40 \mathrm{~nm}$ diameter particles. Nonetheless, among the four simulations NEWSCAV has the closest-to-zero bias for the $20-100 \mathrm{~nm}$ and $100-500 \mathrm{~nm}$ diameter particles at Mt. Zeppelin in summer. As well, at Alert, the summertime Aitken-mode bias for simulation NEWSCAV is second smallest (after NEWSCAV+COAG), but the shape of the distribution shown in Fig. 3 is not a perfect match with the observations for either simulation as there are sizes that are strongly over- and underpredicted within the $20-100 \mathrm{~nm}$ diameter range.

Figures 3 and 4 demonstrate the importance of in-cloud coagulation (NEWSCAV $+\mathrm{COAG}$ relative to NEWSCAV) in reducing the number of $20-200 \mathrm{~nm}$ diameter particles in all seasons but to varying degrees. In spring and summer at both sites, this additional coagulation for simulation NEWSCAV+COAG reduces the number of $40-100 \mathrm{~nm}$ diameter particles excessively relative to measurements. As a result, simulation NEWSCAV is a somewhat better match to measurements in this $40-100 \mathrm{~nm}$ diameter range in spring and summer at both sites. However among the four simu- lations, NEWSCAV+COAG has the smallest fractional bias for the Aitken mode in winter and summer at Alert and in winter and spring at Mt. Zeppelin, as well as the smallest springtime accumulation-mode bias at both sites (and smallest summertime accumulation-mode bias at Alert).

Simulation NONUC was designed as a means to assess the relative contribution of NPF processes to the Arctic aerosol size distributions. In our simulations, NPF contributes most strongly to the number of particles smaller than $200 \mathrm{~nm}$. These contributions occur in all seasons as shown by the differences between NEWSVAC and NONUC in Figs. 3 and 4. In the summertime, NPF occurs within the Arctic boundary layer both in our simulations and in observations (Chang et al., 2011; Leaitch et al., 2013; Allan et al., 2015). At this time of year, the Arctic region has greater production of oxidants such as $\mathrm{OH}$ and has greater dimethyl sulfide (DMS) emissions from the oceanic biological activity, such that oxidation of DMS by $\mathrm{OH}$ produces sulfur dioxide $\left(\mathrm{SO}_{2}\right)$ and, ultimately, sulfuric acid, which contributes to particle formation processes in the boundary layer (e.g. Leaitch et al., 2013). In seasons other than summer, transport of particles arising from NPF outside the Arctic or NPF above the Arctic boundary layer contributes more to the number of particles with diameters smaller than $200 \mathrm{~nm}$. The NONUC simulation coincidentally has the lowest bias for the accumulation-mode number in autumn and winter at both sites and for the Aitken mode in autumn at both sites, as well as in spring at Alert. Shutting off the NPF process (a source term) in the model appears to compensate for errors in the key sink terms for aerosol number, such as wet removal and coagulation, and 

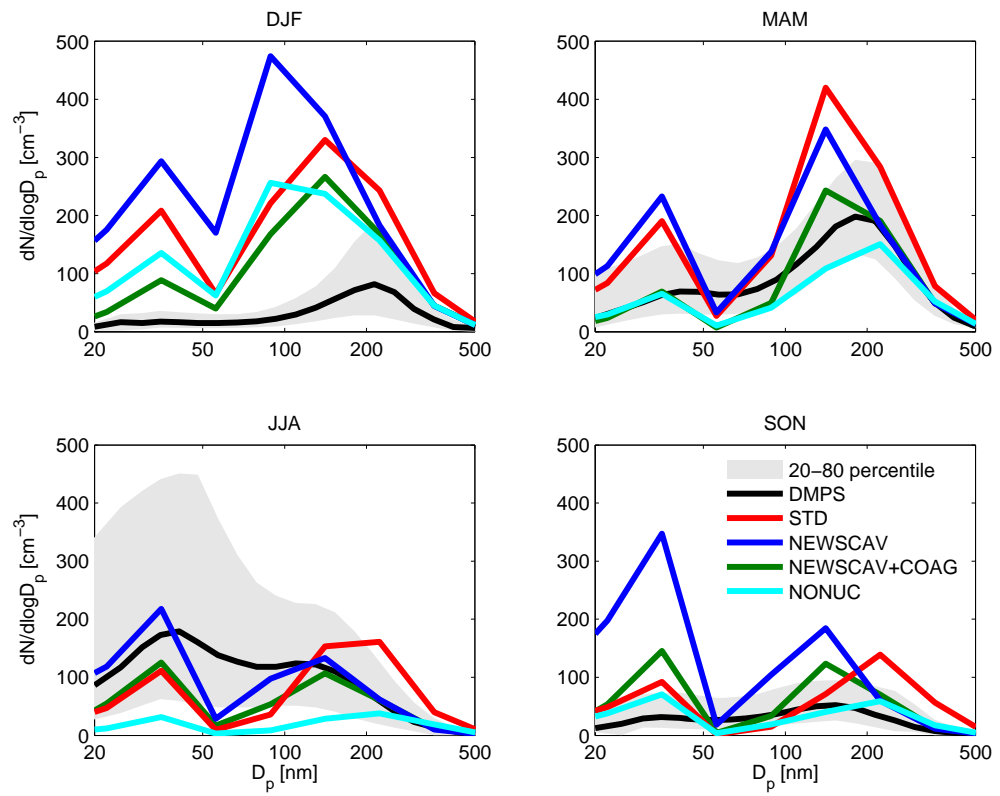

Figure 4. Seasonal-median number distributions from DMPS measurements at Mt. Zeppelin (2011-2013) and for the GEOS-Chem-TOMAS dry size distribution simulations (described in Table 1). The measurement 20-80th percentile is in grey shading. Simulations are shown in colour as indicated by legend.

related feedbacks. In reality, NPF makes a significant contribution to the number concentration in the Arctic (e.g. Chang et al., 2011; Leaitch et al., 2013). The Arctic is a challenging region that tests the performance of the entire set of model mechanisms. Nevertheless, our results, presented in Figs. 3 and 4, highlight NPF and particle growth, wet removal, and coagulation as key processes for controlling Arctic aerosol size distributions throughout the annual cycle.

Figures 5 and 6 show the annual cycle of the monthly median total number of particles with diameters between 20 and $500 \mathrm{~nm}(\mathrm{~N} 20), 80$ and $500 \mathrm{~nm}(\mathrm{~N} 80)$, and 200 and $500 \mathrm{~nm}$ (N200) from simulations and from measurements at Alert and Mt. Zeppelin. To assist with interpreting Figs. 5 and 6, Tables 4 and 5 contain the mean FB (MFB) and mean fractional error (MFE) following Boylan and Russell (2006).

$\operatorname{MFB}=\frac{1}{N} \sum_{i=1}^{i=N} \frac{\left(C_{\mathrm{m}}(i)-C_{o}(i)\right)}{\left(C_{\mathrm{m}}(i)+C_{o}(i)\right) / 2}$,

$\mathrm{MFE}=\frac{1}{N} \sum_{i=1}^{i=N} \frac{\left|C_{\mathrm{m}}(i)-C_{o}(i)\right|}{\left(C_{\mathrm{m}}(i)+C_{o}(i)\right) / 2}$,

where $C_{\mathrm{m}}(i)$ is the $i$ th monthly model value, $C_{o}(i)$ is the $i$ th monthly measurement value, and $N$ is the total number of months in a year.

Figures 5 and 6 demonstrate the key features of the annual cycle of integrated Arctic aerosol number distributions. Measurements from both Alert and Mt. Zeppelin show a shallow maximum in the $\mathrm{N} 20$ in both spring and summer. The measurement N80 and N200 have a maximum in March-April at both sites. The minimum for the N20, N80, and N200 from measurements occurs near September-October at both sites. All four simulations capture the general trend of N80 and N200 being higher in spring than in autumn, but there are some notable mismatches discussed below.

Similar to our findings in examining the seasonal-mean size distributions (Figs. 3 and 4), Figs. 5 and 6 show that the N200 is highly sensitive to the wet-removal parameterization. Simulation STD overpredicts the N200 at both Alert and Zeppelin as evidenced by the greatest magnitude of the N200 MFB and MFE among the four simulations at both sites for simulation STD. Wet removal revisions for simulation NEWSCAV reduce the N200 MFB and MFE towards 0, whereas implementation of the new coagulation mechanism has a lesser effect on these N200 biases. NONUC has the closest-to-zero MFB for N200 among the four simulations at both Alert and Zeppelin and also the lowest MFE at Alert. However, the MFE for the N200 is similar between NONUC and NEWSCAV +COAG at both sites. As noted earlier, suppressing particle formation in NONUC likely compensates for errors in sink processes.

The N20 and N80 are sensitive to the wet-removal and coagulation schemes. Tables 4 and 5 show that interstitial coagulation (NEWSCAV+COAG relative to NEWSCAV) reduces the MFB and MFE for N20 and N80 at both Alert and Mt. Zeppelin. However, changes to the wet-removal parameterization increase the N20 and N80 MFB and MFE at both sites for simulation NEWSCAV relative to STD, except for the N80 MFB at Mt. Zeppelin. As discussed in reference to Figs. 3 and 4, NPF increases when the wet removal is more vigorous, and these new particles grow to increase 

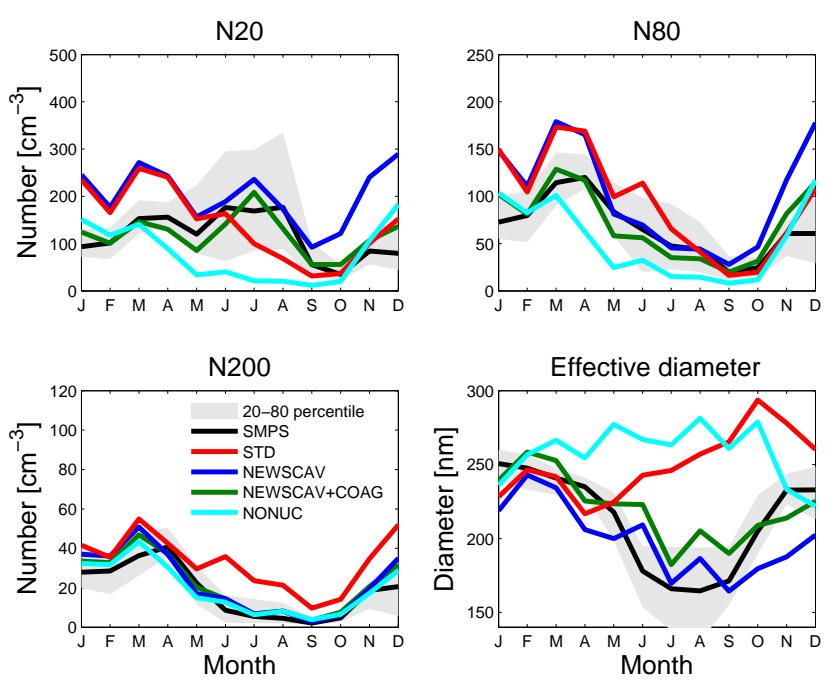

Figure 5. Monthly median number concentration for aerosols with diameters of 20-500 nm (N20), 80-500 nm (N80), and 200-500 nm (N200) and effective diameter from the 2011-2013 Alert SMPS measurements and for the four GEOS-Chem-TOMAS dry size distribution simulations described in Table 1. The measurement 2080th percentile is in grey shading. Simulations are shown in colour as indicated by legend.

Table 4. Model-measurement mean fractional bias and mean fractional error (Eqs. 7 and 8) for N20, N80, N200, and effective diameter at Alert (in reference to Fig. 5). Bias and error values closest to zero for each season are highlighted in bold.

\begin{tabular}{lrrrr}
\hline & STD & NEWSCAV & $\begin{array}{r}\text { NEWSCAV } \\
+ \text { COAG }\end{array}$ & NONUC \\
\hline MFB & & & & \\
\hline N20 & 0.22 & 0.57 & $\mathbf{0 . 0 6}$ & -0.53 \\
N80 & 0.24 & 0.36 & $\mathbf{0 . 0 5}$ & -0.43 \\
N200 & 0.74 & 0.24 & 0.27 & $\mathbf{0 . 1 7}$ \\
Eff. diam. & 0.17 & $-\mathbf{0 . 0 5}$ & $\mathbf{0 . 0 5}$ & 0.21 \\
\hline MFE & & & & \\
\hline N20 & 0.45 & 0.57 & $\mathbf{0 . 2 3}$ & 0.80 \\
N80 & 0.32 & 0.37 & $\mathbf{0 . 2 3}$ & 0.60 \\
N200 & 0.74 & 0.30 & 0.30 & $\mathbf{0 . 2 9}$ \\
Eff. diam. & 0.20 & 0.10 & $\mathbf{0 . 0 8}$ & 0.22 \\
\hline
\end{tabular}

the number of Aitken-mode aerosols in the simulations (i.e. the condensation sink for condensable vapours on to existing aerosols is lower, which favours NPF and growth and reduces losses of new particles by coagulation). At Mt. Zeppelin for the N20 and N80, NONUC has the smallest MFB but NEWSCAV+COAG best represents the annual cycle (smallest MFE) among the four simulations. At Alert, for the N20 and N80, NEWSCAV+COAG best represents the annual cycle (smallest MFE and MFB).

Figures 5 and 6 also show the annual cycle of aerosol effective diameter at both Alert and Mt. Zeppelin for
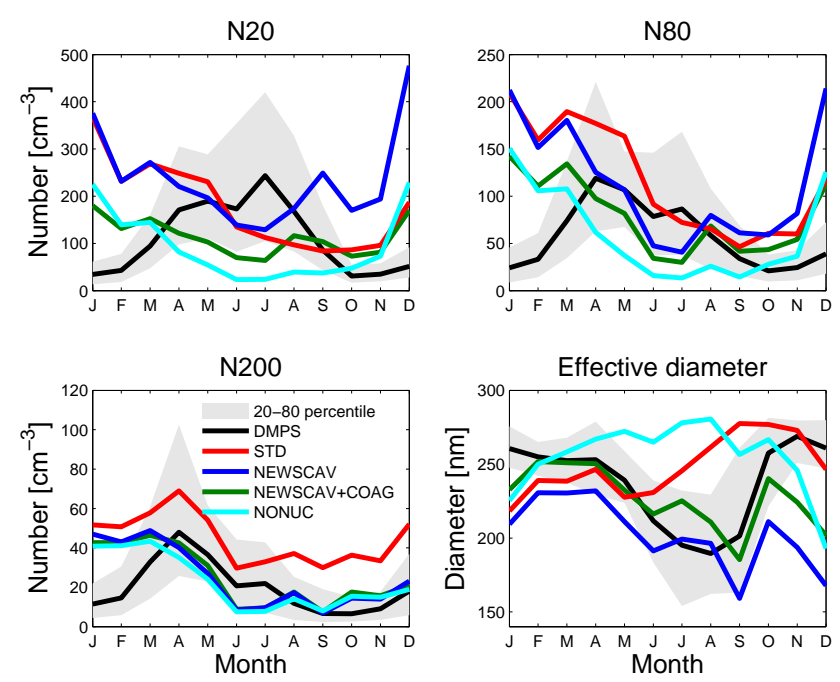

Figure 6. Monthly median number concentration for aerosols with diameters of 20-500 nm (N20), 80-500 nm (N80), and 200-500 nm (N200) and effective diameter from the 2011-2013 Mt. Zeppelin DMPS measurements and for the four GEOS-Chem-TOMAS dry size distribution simulations described in Table 1. The measurement $20-80$ th percentile is in grey shading. Simulations are shown in colour as indicated by legend.

our simulations and from measurements. The simulation NEWSCAV+COAG has the closest agreement (smallest MFE) with the annual cycle of effective diameter from the measurements for both sites. At Alert, the aerosol effective diameter has the smallest bias for both NEWSCAV and NEWSCAV+COAG, whereas at Mt. Zeppelin STD has the smallest bias for the effective diameter due to cancellation of errors between months of over- and underprediction. The simulations overpredict the aerosol effective diameter in July and August, except for NEWSCAV at Mt. Zeppelin. The overprediction of summertime effective diameter is pronounced for the simulation NONUC that removes NPF, illustrating the importance of NPF in yielding the summertime minimum effective diameter. The effective diameter in winter at Mt. Zeppelin is strongly underestimated in all simulations, reflecting too many small (Aitken mode) particles, even for simulation NONUC.

The similarity in the annual cycle of effective diameter from measurements at both Alert and Zeppelin suggests a cycle that occurs throughout the Arctic. Figure 7 shows the seasonal-mean pan-Arctic geographic distribution of the surface-layer effective diameter for the NEWSCAV+COAG simulation. Throughout the Arctic, the simulated effective diameter declines to a minimum in summer. In Fig. 7, we superimpose the effective diameter from observations at Alert and Mt. Zeppelin. The simulated effective diameter at the altitude of Mt Zeppelin $(500 \mathrm{~m})$ is smaller than the surface value shown here (by $35 \mathrm{~nm}$ in summer, $20 \mathrm{~nm}$ in autumn, and $5 \mathrm{~nm}$ in winter and spring). 


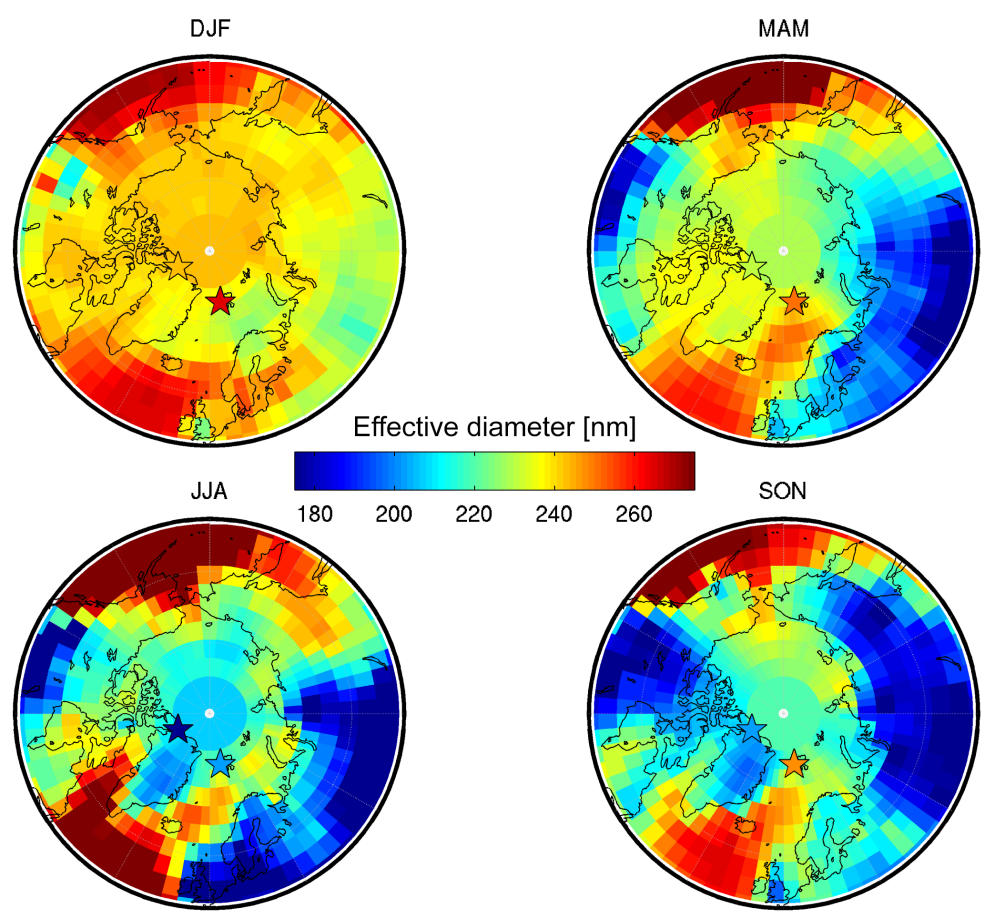

Figure 7. Geographic distribution of the simulated pan-Arctic surface-layer seasonal-mean dry effective diameter (nm) for the NEWSCAV+COAG simulation. The coloured stars indicate the effective diameter from measurements at Alert (SMPS) and Mt. Zeppelin (DMPS).

\subsection{Process rates controlling the annual cycle in Arctic aerosol number and size}

Figure 8 shows the monthly- and regional-mean process rates that control aerosol number in four size ranges for the entire troposphere north of the Arctic Circle $\left(66^{\circ} \mathrm{N}\right)$ for simulation NEWSCAV+COAG. Source processes for aerosol number are positive and sink processes are negative.

The number of aerosols smaller than $10 \mathrm{~nm}$ in diameter (nucleation-mode size) is primarily controlled by NPF (particle formation, also termed nucleation), coagulation, and transport. There are two maxima in the particle formation rate shown in Fig. 8 (top-left panel), one in early spring (March), and one in summer (July). In spring, simulated NPF occurs mainly in the free troposphere, whereas in summer, NPF occurs also in the boundary layer. In the summertime Arctic boundary layer, NPF is enhanced by the low aerosol surface area due to efficient wet removal of accumulationmode aerosols by episodic rain and summer enhancements in sulfuric acid production rates (from oxidation of DMS). The simulated early-spring NPF rate maximum for nucleationsize particles is associated with NPF in the middle and upper troposphere and as a result is not evident in the measurements at Alert and Mt. Zeppelin. This simulated springtime maximum in NPF occurs because the precursors for sulfuric acid (DMS, $\mathrm{SO}_{2}$ ) are transported from open ocean areas and pollution sources at lower latitudes. Then NPF proceeds
Table 5. Model-measurement mean fractional bias and mean fractional error (Eqs. 7 and 8) for N20, N80, N200, and effective diameter at Mt. Zeppelin (in reference to Fig. 6). Bias and error values closest to zero for each season are highlighted in bold.

\begin{tabular}{lrrrr}
\hline & STD & NEWSCAV & $\begin{array}{r}\text { NEWSCAV } \\
+ \text { COAG }\end{array}$ & NONUC \\
\hline MFB & & & & \\
\hline N20 & 0.46 & 0.66 & 0.21 & $-\mathbf{0 . 1 8}$ \\
N80 & 0.65 & 0.57 & 0.31 & $-\mathbf{0 . 1 1}$ \\
N200 & 0.86 & 0.20 & 0.22 & $\mathbf{0 . 1 2}$ \\
Eff. diam. & $\mathbf{0 . 0 4}$ & -0.17 & -0.07 & 0.06 \\
\hline MFE & & & & \\
\hline N20 & 0.76 & 0.86 & $\mathbf{0 . 7 5}$ & 1.03 \\
N80 & $\mathbf{0 . 6 8}$ & 0.77 & $\mathbf{0 . 6 8}$ & 0.88 \\
N200 & 0.86 & 0.66 & $\mathbf{0 . 5 4}$ & 0.56 \\
Eff. diam. & 0.12 & 0.17 & $\mathbf{0 . 1 0}$ & 0.17 \\
\hline
\end{tabular}

in locations where the condensation sink for sulfuric acid on existing aerosols is low such as following wet scavenging episodes.

The top-left panel of Fig. 8 shows that transport reaches a maximum during winter, while NPF reaches a minimum such that the two are comparable sources for the entire Arctic troposphere. Simulated NPF occurs in the dark Arctic 

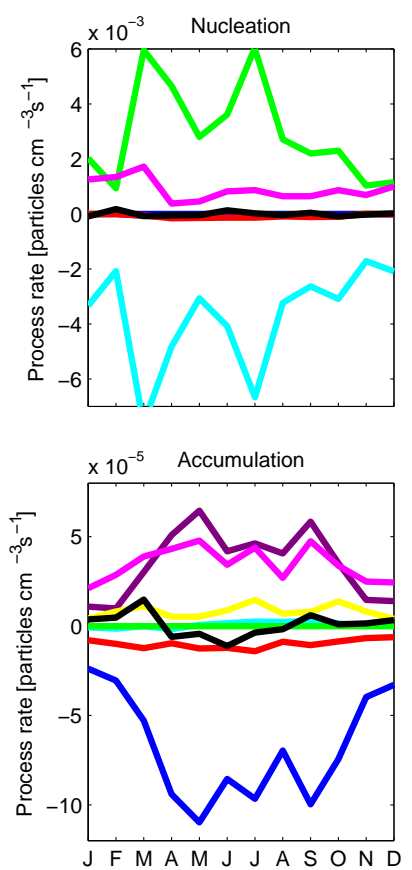

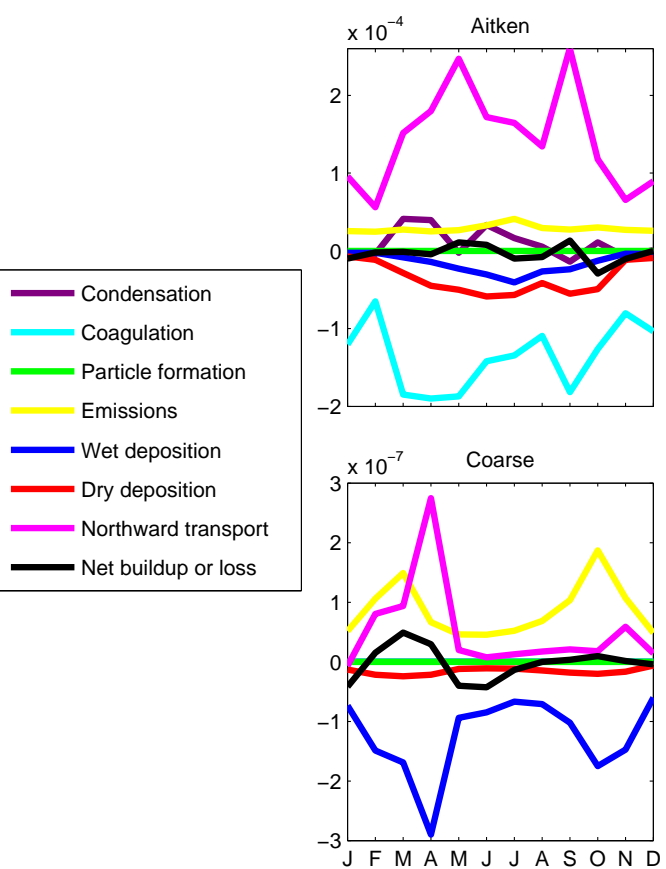

Figure 8. Monthly and Arctic mean aerosol number process rates for the entire Arctic troposphere (north of $66^{\circ} \mathrm{N}$ ) for simulation NEWSCAV+COAG. Processes considered for each of four size ranges are condensation, coagulation, particle formation, primary emissions, wet and dry deposition, transport across $66^{\circ} \mathrm{N}$, and net regional buildup or loss rates. The aerosol size ranges are nucleation $\left(D_{\mathrm{p}}<10 \mathrm{~nm}\right)$, Aitken $\left(10<D_{\mathrm{p}}<100 \mathrm{~nm}\right)$, accumulation $\left(100<D_{\mathrm{p}}<1000 \mathrm{~nm}\right)$, and coarse $\left(D_{\mathrm{p}}>1000 \mathrm{~nm}\right)$.

wintertime since the oxidant $\mathrm{OH}$ is produced through reaction of ozone and volatile organic compounds, although the $\mathrm{OH}$ mixing ratios are 3-fold less than in summer. As a result, sulfuric acid (a particle precursor vapour) can be produced though oxidation by $\mathrm{OH}$ of DMS and sulfur dioxide $\left(\mathrm{SO}_{2}\right)$ transported into the Arctic in winter. Our simulated Arctic wintertime sulfuric acid mixing ratio is about $0.01 \mathrm{ppt}$ near the tropopause and diminishes towards the Earth's surface. Measurements by Möhler and Arnold (1992) indicate wintertime sulfuric acid levels in northern Scandinavia of about $0.1 \mathrm{ppt}$ near the tropopause decreasing to $0.01 \mathrm{ppt}$ near the Earth's surface, implying the true nucleation rate could be even higher.

Figure 9 shows aerosol number transport rates at different altitudes by decomposing the rates from Fig. 8 into four altitude bands. Nucleation-mode particles are mostly transported in the mid- to upper troposphere (at altitudes between 4 and $10 \mathrm{~km}$ ) where the coagulation sink is sufficiently low that nucleation-mode particles can persist. At these altitudes and particularly when the atmosphere has just been cleaned by a precipitation event, if the Aitken- and accumulationmode concentrations are low $\left(5-10 \mathrm{~cm}^{-3}\right)$ then nucleationmode particles can have a lifetime of about 1 week with respect to loss by coagulation. Transport rates for nucleation size-particles are greatest from January to March.

Figure 8 (top-right panel) indicates that several processes control the simulated Aitken-mode number in the Arctic tro- posphere. Northward transport is the dominant source process for the Arctic Aitken mode during all months of the year. This transport of simulated Aitken-mode aerosols occurs throughout the troposphere as shown in Fig. 9. Figure 8 shows that during the Arctic spring (March-April), when the total aerosol mass is greatest, condensational growth of existing aerosols makes a relatively greater contribution to the total source rates for Aitken-mode particles. This net enhancement in condensational growth includes condensational loss of Aitken-mode particles to accumulation-mode sizes such that the nucleation mode is a larger source of Aitken-mode particles than apparent in the figure. Simulated primary particle emissions within the Arctic have a relatively constant source rate for the Aitken mode throughout the year, quite similar in magnitude to the maximum condensational growth rate in March-April. Coagulation is the dominant sink for the Aitken mode with dry deposition accounting for the majority of the remaining sink. Simulated removal of the Aitkenmode number by wet deposition is a weaker sink than dry deposition because the smaller Aitken-mode aerosols have inefficient removal by activation scavenging (the process of aerosols acting as the seed for cloud-droplet and ice-crystal formation and subsequent removal during precipitation). Recent studies indicate that aerosols as small as $50-60 \mathrm{~nm}$ can activate in the clean Arctic summertime conditions (Leaitch et al., 2013, 2016) and we likely underestimate this removal in our simulations. Figure 8 does show an increase in wet 

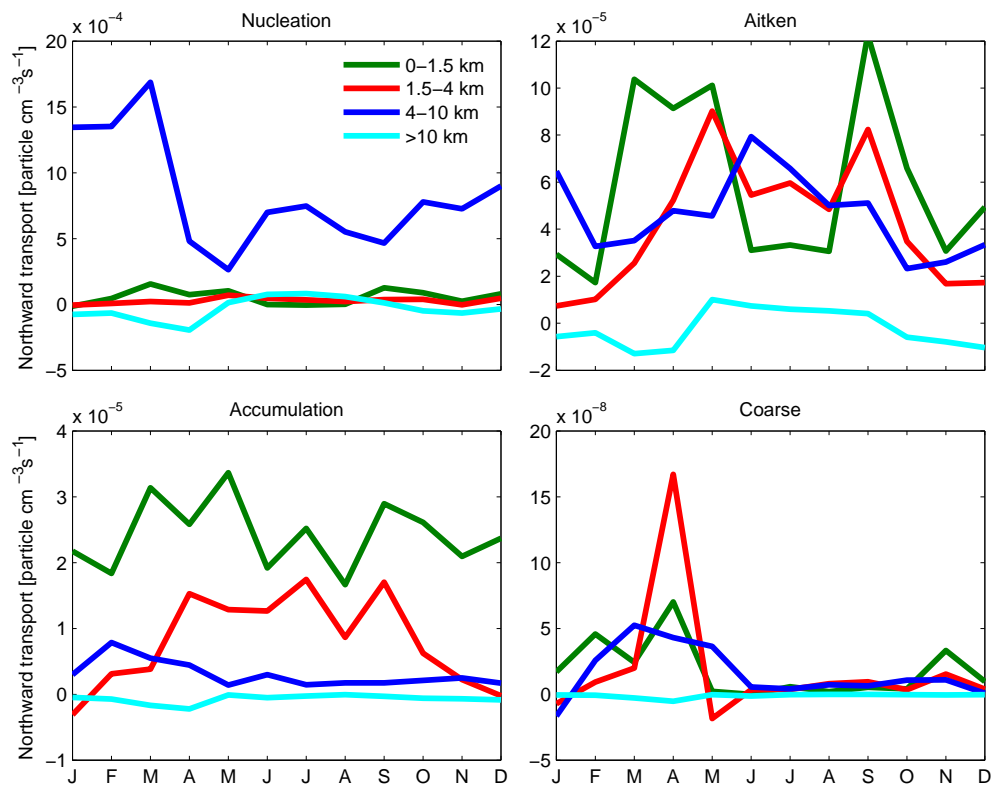

Figure 9. Monthly and Arctic mean aerosol number tendency due to transport within each of four vertical layers between (1) $0-1.5 \mathrm{~km}$, (2) $1.5-4 \mathrm{~km},(3) 4-10 \mathrm{~km}$, and (4) above $10 \mathrm{~km}$ for the simulation NEWSCAV+COAG for the entire troposphere north of $66^{\circ} \mathrm{N}$. Summation of the four layers for any given month and size range yields the transport tendency shown in Fig. 8. Positive values indicate a net northward transport into the Arctic.

removal as a sink for the Aitken mode in summer as this process becomes more efficient at warmer temperatures and aerosols larger than about $60 \mathrm{~nm}$ are removed by activation scavenging in our simulations.

For the accumulation-mode particle number simulation, Fig. 8 (bottom-left panel) indicates that the dominant sources are northward transport and condensational growth, which also includes production of sulfate by in-cloud oxidation. These two simulated source terms are roughly equal in magnitude in the Arctic throughout April to October. Northward transport of accumulation-mode aerosols persists in the simulation in all seasons, with a minimum in winter and an increase in March-April. Figure 9 shows that transport of accumulation size aerosol at altitudes between 1.5 and $4 \mathrm{~km}$ reaches a maximum in April, which would contribute to the well-known Arctic haze phenomena. Figure 9 also shows that the majority of simulated accumulation-mode number transport is below $1.5 \mathrm{~km}$. This low-level transport is persistent though diminished throughout the summer, suggesting that the summertime cleanliness of the Arctic near-surface atmosphere relies heavily on the increased efficiency of the removal processes in the lower troposphere during the summer months. Indeed, Fig. 8 shows that wet removal is the dominant accumulation aerosol number sink process in all seasons, but it increases in magnitude and relative importance with respect to dry deposition in the summer, accounting for about $90 \%$ of the total summertime sink rate. In winter, the relative simulated importance of dry deposition for accumu- lation aerosol number increases, although it remains below $25 \%$ of the total sink rate.

Since wet removal has large effects on the accumulation aerosol number associated with Arctic springtime pollution, we further examined its annual cycle. Figure 10 shows the monthly- and regional-mean accumulation-mode number lifetime with respect to wet removal for layers of the lower troposphere. Longer lifetimes from December to March contribute to the build up of the Arctic haze layer, particularly as this is combined with transport of pollution into the Arctic during wintertime. The spring to summer transition period is characterized by a rapid increase in the efficiency of wet scavenging that contributes to removal of the Arctic haze in April-May. Figure 10 shows about a 5-fold decrease in wetremoval lifetime in the Arctic 1.5-4 km layer from February to April. Simulated wet-removal lifetimes in the Arctic boundary layer below $1.5 \mathrm{~km}$ reach a minimum in October, such that when combined with diminishing new-particle formation as the sunsets and limited transport yields the simulated total aerosol number minimum in the autumn season, similar to that observed at Alert and Mt. Zeppelin. To put the Arctic region in context, Fig. 10 also shows the lifetimes with respect to wet removal for the region north of $50^{\circ} \mathrm{N}$, indicating that wet-removal processes are generally more efficient for a region with greater southward extent and at lower altitudes.

Figure 8 shows that the simulated coarse mode is controlled primarily by emissions, transport and wet deposition. In early spring (March-April), northward transport of 


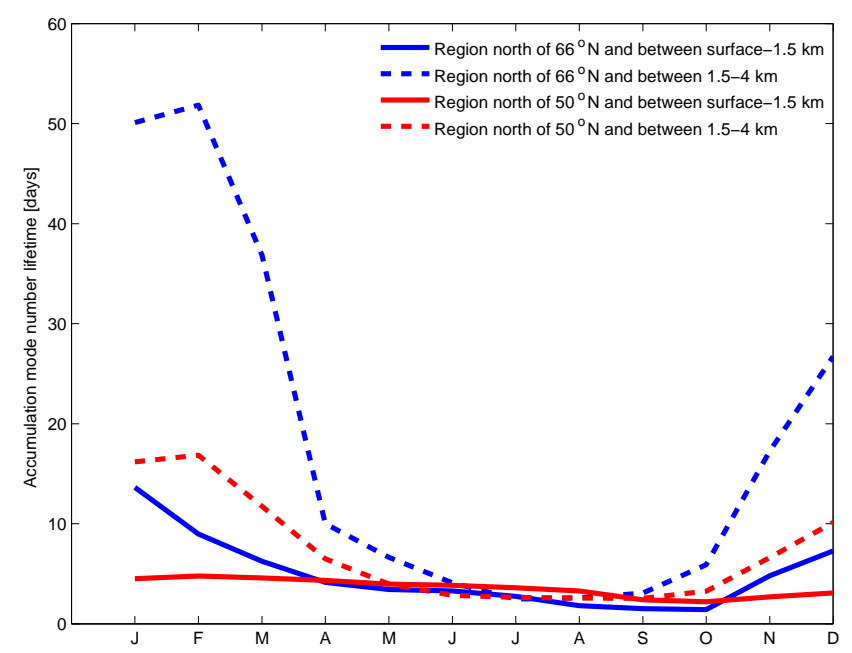

Figure 10. Regional- and monthly-mean aerosol number lifetime with respect to wet deposition for accumulation-mode aerosol numbers $\left(100<D_{\mathrm{p}}<1000 \mathrm{~nm}\right)$ and in the altitude bands of $0-1.5 \mathrm{~km}$ and $1.5-4 \mathrm{~km}$ for the GEOS-Chem simulation NEWSCAV+COAG.

coarse-mode aerosols (dust and sea-salt emissions) is not quite matched by the removal processes. The resultant residual (black line on Fig. 8) gives the net rate of either aerosol build-up or loss for the regional monthly mean number. In early spring, there is a net build-up of coarse-mode aerosol in the Arctic region. However as spring progresses, there is a net loss such that the net residual integrates to 0 over the annual cycle. Wet removal is the primary loss process in all seasons in this simulation. Figure 9 shows that the early-springtime transport of the coarse mode occurs mainly at altitudes between 1.5 and $4 \mathrm{~km}$, a time when the polar dome still extends relatively far southward.

In this section we examined process rates over the entire troposphere north of $66^{\circ} \mathrm{N}$. To put these Arctic process rates in context with other regions, Fig. 11 shows the same set of processes for the same four aerosol size ranges over the entire troposphere north of $50^{\circ} \mathrm{N}$. Several differences are apparent. For the nucleation, Aitken, and accumulation sizes, transport is of negligible importance relative to other source processes, unlike for the Arctic region. Coagulation remains the main sink for the number of nucleation- and Aitken-mode aerosols as shown in Figs. 8 and 11, but the relative importance of wet removal of the Aitken mode in summer has diminished. Wet removal rates for the accumulation-mode aerosol number reach a maximum in May in the Arctic whereas the maximum is in July for the entire region north of $50^{\circ} \mathrm{N}$. For the Aitken and accumulation modes, condensational growth is the dominant source north of $50^{\circ} \mathrm{N}$, unlike for the Arctic region only (Fig. 8) where transport was of similar or greater importance. The coarse mode north of $50^{\circ} \mathrm{N}$ shows a peak in the transport source in April, similar to Fig. 8, associated with transport of dust from lower latitudes in spring. Coarseparticle number wet removal also shows an April maximum in both Figs. 8 and 11. The global mean simulated number process rates (not shown) show a relative importance of processes similar to that in Fig. 11, except in the global mean, primary emissions are the only non-negligible source of coarse aerosol number throughout the year. Wet deposition remains the dominant sink of accumulation and coarse-mode number, followed by dry deposition at the global scale, as in the Arctic.

\section{Conclusions}

In this study, we examined the annual cycle of aerosol number and size distributions in the Arctic from measurements made during 2011-2013 by SMPS at Alert and by DMPS at Mt. Zeppelin. There was a strong and similar annual cycle in measurements of aerosol number and size at both sites despite their geographic separation of $1000 \mathrm{~km}$. The annual cycle in the total number of aerosols larger than $20 \mathrm{~nm}$ had two maxima. The maximum in spring was dominated by accumulation-mode aerosols (particles 100 to $500 \mathrm{~nm}$ in diameter) and in summer was dominated by Aitken-mode aerosols (particles 20 to $100 \mathrm{~nm}$ in diameter). At both sites, total aerosol number reached a minimum in October. The annual cycle of aerosol effective diameter derived from measurements had an inter-seasonal range between 180 and $260 \mathrm{~nm}$, with a minimum in the summer. These annual cycles were similar to those presented by Tunved et al. (2013) based on earlier data at Mt. Zeppelin between the years 2000 and 2010.

We interpreted these annual cycles in Arctic aerosol number and size with the GEOS-Chem-TOMAS aerosol microphysics model. Our simulations indicated a strong sensitivity of the annual cycle of Arctic aerosol number and size to several key processes: new-particle formation, interstitial coagulation scavenging in clouds, wet removal through precipitation, and transport.

Our GEOS-Chem-TOMAS simulations demonstrated that wet removal had a strong control on Arctic aerosol number distributions throughout the annual cycle, similar to the findings of earlier studies focused on spring-summer (Korhonen et al., 2008) and Arctic aerosol mass abundance (e.g. Garrett et al., 2010; Browse et al., 2012; Sharma et al., 2013). In our study, wet-removal updates were developed for the GEOSChem-TOMAS model that together increased the efficiency of wet removal. We replaced the global-constant cloud liquid water content with the values from GEOS-5 assimilated meteorology fields, updated the grid-box precipitation fraction, and implemented the Verheggen et al. (2007) temperaturedependent aerosol activation fraction to account for the fraction of aerosol assumed to be susceptible to wet removal in mixed-phase clouds. In our updated removal simulation, efficient wet removal in the Arctic summertime boundary layer strongly limited the accumulation-mode number despite an ongoing source through transport and condensa- 

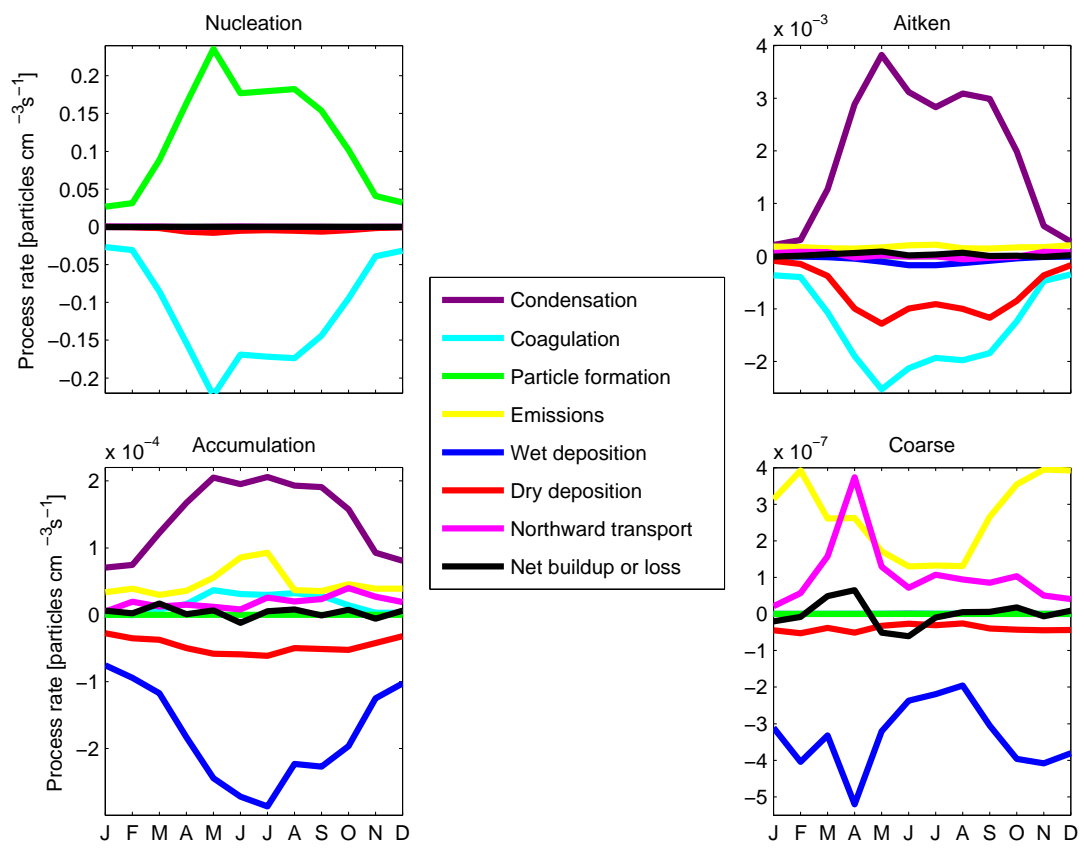

Figure 11. Monthly- and regional-mean aerosol number process rates for the entire troposphere north of $50^{\circ} \mathrm{N}$ for simulation NEWSCAV+COAG. Processes considered for each of four size ranges are nucleation, emissions, coagulation, condensation, wet and dry deposition, transport across $66^{\circ} \mathrm{N}$, and net regional accumulation or loss rates. The aerosol size ranges are nucleation $\left(D_{\mathrm{p}}<10 \mathrm{~nm}\right)$, Aitken $\left(10<D_{\mathrm{p}}<100 \mathrm{~nm}\right)$, accumulation $\left(100<D_{\mathrm{p}}<1000 \mathrm{~nm}\right)$, and coarse $\left(D_{\mathrm{p}}>1000 \mathrm{~nm}\right)$.

tional growth. The wet-removal updates reduced modelmeasurement bias (relative to the standard model) for the number of aerosols larger than $200 \mathrm{~nm}$ in all seasons at both Alert and Mt. Zeppelin (although the changes in winter and spring at Alert were relatively small).

More vigorous wet removal promoted NPF and growth in our simulations and contributed to a summertime-dominant Aitken mode since a reduction in the surface area of accumulation size aerosols (the condensation sink for sulfuric acid) influences the likelihood that sulfuric acid will participate in NPF as opposed to condensing on existing aerosols. Indeed, the more vigorous wet-removal scheme increased the simulated Aitken-mode number in all seasons at Alert and Mt. Zeppelin (although the springtime Aitken mode was relatively less sensitive to the changes made in our study). Outside of summer, NPF and growth occurred mostly outside the Arctic boundary layer. A sensitivity study with no NPF globally indicated that NPF strongly controls the number of particles with diameters smaller than $200 \mathrm{~nm}$ in all seasons in the Arctic, while particularly important in yielding the summertime Aitken-mode dominance.

From February to April, the simulated accumulation-mode wet-removal efficiency at altitudes of the springtime Arctic haze layer (between 1.5 and $4 \mathrm{~km}$ ) increased by 5 -fold, contributing to our simulation of the spring-summer transition from Aitken- to accumulated-mode dominated Arctic size distributions (e.g. Engvall et al., 2008; Korhonen et al., 2008). In the boundary layer, simulated wet-removal efficiency reached a maximum (lowest accumulation-mode aerosol number lifetime) in October. The observed total aerosol number minimum in October was reproduced in our simulations due to efficient wet removal combined with diminished boundary layer NPF due to lower sulfuric acid concentrations and limited transport.

We also found an important role for coagulation of interstitial aerosols in clouds with aerosols of larger size that have activated to form cloud droplets. There has been relatively less attention given to the importance of this process in controlling Arctic size distributions despite the Arctic being a region with widespread cloud cover in all seasons. Implementation of an interstitial coagulation mechanism in clouds in our simulations reduced the number of aerosols with diameters smaller than $200 \mathrm{~nm}$ in all seasons at both Alert and Mt. Zeppelin. In some seasons this reduction in the Aitken-mode number worsened model-measurement agreement, highlighting the delicate balance between the processes of coagulation, NPF, growth, and wet removal in control of the Arctic size distributions that is challenging to simulate. Our simulations tended to under predict the number of larger Aitken-mode aerosols $(40-100 \mathrm{~nm}$ in diameter) in summer and this is the subject of ongoing investigation related to aerosol sources and growth.

The high sensitivity of aerosol number to interstitial coagulation in clouds suggests that size-resolved models should 
include this process. However, many present-day global models neglect this process, including previous versions of GEOS-Chem-TOMAS (D'Andrea et al., 2013; Pierce et al., 2013; Trivitayanurak et al., 2008), GISS-TOMAS (Adams and Seinfeld, 2002; Pierce and Adams, 2009), GLOMAP (Spracklen et al., 2005a, b, 2008; Mann et al., 2012), GLOMAP-Mode (Mann et al., 2010, 2012; L. A. Lee et al., 2013), GEOS-Chem-APM (Yu and Luo, 2009; Yu, 2011), and IMPACT (Herzog et al., 2004; Wang and Penner, 2009). To our knowledge, only a few models such as MIRAGE and ECHAM-HAM (Herzog et al., 2004; Ghan et al., 2006; Hoose et al., 2008) represent this process.

Our results highlight the importance of aerosol processes (as well as their delicate balance and interactions) that continue to be poorly understood: (1) NPF and growth, (2) incloud interstitial coagulation, and (3) wet removal play a key role in the control of the annual cycle of aerosol number and size in the Arctic. The relative importance of the processes that control aerosol number could change in a future warming Arctic climate and also as emissions within the Arctic change.

Acknowledgements. The authors acknowledge the financial support provided for NETCARE through the Climate Change and Atmospheric Research Program at NSERC Canada. Thanks to Sangeeta Sharma, Desiree Toom, Andrew Platt, and the Alert operators for supporting the Alert observations. We are also grateful to Ilona Riipinen, Jan Julin, and Tinya Olenius for helpful discussions and for providing the Atmospheric Cluster Dynamics Code (ACDC), applied in our GEOS-Chem-TOMAS simulations.

Edited by: H. Wang

\section{References}

Adams, P. J. and Seinfeld, J. H.: Predicting global aerosol size distributions in general circulation models, J. Geophys. Res., 107, 4310-4370, 2002.

Albrecht, B. A.: Aerosols, Cloud Microphysics, and Fractional Cloudiness, Science, 245, 1227-1230, 1989.

Allan, J. D., Williams, P. I., Najera, J., Whitehead, J. D., Flynn, M. J., Taylor, J. W., Liu, D., Darbyshire, E., Carpenter, L. J., Chance, R., Andrews, S. J., Hackenberg, S. C., and McFiggans, G.: Iodine observed in new particle formation events in the Arctic atmosphere during ACCACIA, Atmos. Chem. Phys., 15, 55995609, doi:10.5194/acp-15-5599-2015, 2015.

Baranizadeh, E., Murphy, B. N., Julin, J., Falahat, S., Reddington, C. L., Arola, A., Mikkonen, S., Fountoukis, C., Patoulias, D., Minikin, A., Hambuger, T., Laaksonen, A., Pandis, S. N., Vehkamäki, H., Lehtinen, K. E. J., and Riipinen, I.: Implementation of state-of-the-art ternary new particle formation scheme to the regional chemical transport model PMCAMx-UF in Europe, Geosci. Model Dev. Discuss., doi:10.5194/gmd-2016-21, in review, 2016.

Bey, I., Jacob, D. J., Yantosca, R. M., Logan, J. A., Field, B. D., Fiore, A. M., Li, Q., Liu, H. Y., Mickley, L. J., and Schultz,
M. G.: Global modeling of tropospheric chemistry with assimilated meteorology: Model description and evaluation, J. Geophys. Res., 106, 23073, doi:10.1029/2001JD000807, 2001.

Boylan, J. W. and Russell, A. G.: PM and light extinction model performance metrics, goals, and criteria for three-dimensional air quality models, Atmos. Environ., 40, 4946-4959, 2006.

Browse, J., Carslaw, K. S., Arnold, S. R., Pringle, K., and Boucher, O.: The scavenging processes controlling the seasonal cycle in Arctic sulphate and black carbon aerosol, Atmos. Chem. Phys., 12, 6775-6798, doi:10.5194/acp-12-6775-2012, 2012.

Browse, J., Carslaw, K. S., Mann, G. W., Birch, C. E., Arnold, S. R., and Leck, C.: The complex response of Arctic aerosol to sea-ice retreat, Atmos. Chem. Phys., 14, 7543-7557, doi:10.5194/acp14-7543-2014, 2014.

Cesana, G., Kay, J. E., Chepfer, H., English, J. M., and de Boer, G.: Ubiquitous low-level liquid-containing Arctic clouds: New observations and climate model constraints from CALIPSO-GOCCP, Geophys. Res. Lett., 39, L20804, doi:10.1029/2012GL053385, 2012.

Chang, R. Y.-W., Leck, C., Graus, M., Müller, M., Paatero, J., Burkhart, J. F., Stohl, A., Orr, L. H., Hayden, K., Li, S.-M., Hansel, A., Tjernström, M., Leaitch, W. R., and Abbatt, J. P. D.: Aerosol composition and sources in the central Arctic Ocean during ASCOS, Atmos. Chem. Phys., 11, 10619-10636, doi:10.5194/acp-11-10619-2011, 2011.

Charlson, R. J., Schwartz, S. E., Hales, J. M., Cess, R. D., Coakley, J. A., Hansen, J. E., and Hofman, D. J.: Climate Forcing by Anthropogenic Aerosols, Science, 255, 423-430, 1992.

D’Andrea, S. D., Häkkinen, S. A. K., Westervelt, D. M., Kuang, C., Levin, E. J. T., Kanawade, V. P., Leaitch, W. R., Spracklen, D. V., Riipinen, I., and Pierce, J. R.: Understanding global secondary organic aerosol amount and size-resolved condensational behavior, Atmos. Chem. Phys., 13, 11519-11534, doi:10.5194/acp-1311519-2013, 2013.

Di Pierro, M., Jaeglé, L., Eloranta, E. W., and Sharma, S.: Spatial and seasonal distribution of Arctic aerosols observed by the CALIOP satellite instrument (2006-2012), Atmos. Chem. Phys., 13, 7075-7095, doi:10.5194/acp-13-7075-2013, 2013.

Donahue, N. M., Trump, E. R., Pierce, J. R., and Riipinen, I.: Theoretical constraints on pure vapour-pressure driven condensation of organics to ultrafine particles, Geophys. Res. Lett., 38, L16801, doi:10.1029/2011GL048115, 2011.

Engvall, A. C., Krejci, R., Ström, J., Minikin, A., Treffeisen, R., Stohl, A., and Herber, A.: In-situ airborne observations of the microphysical properties of the Arctic tropospheric aerosol during late spring and summer, Tellus B, 60, 392-404, doi:10.1111/j.1600-0889.2008.00348.x, 2008.

Fu, P. Q., Kawamura, K., Chen, J., Charrière, B., and Sempéré, R.: Organic molecular composition of marine aerosols over the Arctic Ocean in summer: contributions of primary emission and secondary aerosol formation, Biogeosciences, 10, 653-667, doi:10.5194/bg-10-653-2013, 2013.

Fuchs, N. A.: Mechanics of Aerosols, Pergamon, New York, 1964.

Garrett, T. J., Zhao, C., and Novelli, P. C.: Assessing the relative contributions of transport efficiency and scavenging to seasonal variability in Arctic aerosol, Tellus B, 62, 190-196, doi:10.1111/j.1600-0889.2010.00453.x, 2010.

Garrett, T. J., Brattström, S., Sharma, S., Worthy, D. E. J., and Novelli, P.: The role of scavenging in the seasonal transport of black 
carbon and sulfate to the Arctic, Geophys. Res. Lett., 38, L16805, doi:10.1029/2011GL048221, 2011.

Gettelman, A., Morrison, H., Terai, C. R., and Wood, R.: Microphysical process rates and global aerosol-cloud interactions, Atmos. Chem. Phys., 13, 9855-9867, doi:10.5194/acp-13-98552013, 2013

Ghan, S. J., Rissman, T. A., Elleman, R., Ferrare, R. A., Turner, D., Flynn, C., Wang, J., Ogren, J., Hudson, J., Jonsson, H. H., VanReken, T., Flagan, R. C., and Seinfeld, J. H.: Use of in situ cloud condensation nuclei, extinction, and aerosol size distribution measurements to test a method for retrieving cloud condensation nuclei profiles from surface measurements, J. Geophys. Res., 111, D05S10, doi:10.1029/2004JD005752, 2006.

Giamarelou, M., Eleftheriadis, K., Nyeki, S., Tunved, P., Torseth, K., and Biskos, G.: Indirect evidence of the composition of nucleation mode atmospheric particles in the high Arctic, J. Geophys. Res., 121, 965-975, doi:10.1002/2015JD023646, 2016.

Giorgi, F. and Chameides, W. L.: Rainout Lifetimes of Highly Soluble Aerosols and Gases as Inferred From Simulations With a General Circulation Model, J. Geophys. Res., 91, 14367-14376, 1986.

Haywood, J. M. and Boucher, O.: Estimates of the Direct and Indirect Radiative Forcing Due to Tropospheric Aerosols: A review, Rev. Geophys., 38, 513-543, 2000.

Heintzenberg, J., Leck, C., Birmili, W., Wehner, B., Tjernstrom, M., and Wiedensohler, A.: Aerosol number-size distributions during clear and fog periods in the summer high Arctic: 1991, 1996, and 2001, Tellus B, 58, 41-50, 2006.

Heintzenberg, J., Leck, C., and Tunved, P.: Potential source regions and processes of aerosol in the summer Arctic, Atmos. Chem. Phys., 15, 6487-6502, doi:10.5194/acp-15-6487-2015, 2015.

Herzog, M., Weisenstein, D. K., and Penner, J. E.: A dynamic aerosol module for global chemical transport models: Model description, J. Geophys. Res.-Atmos., 109, D18202, doi:10.1029/2003JD004405, 2004.

Hoose, C., Lohmann, U., Bennartz, R., Croft, B., and Lesins, G.: Global simulations of aerosol processing in clouds, Atmos. Chem. Phys., 8, 6939-6963, doi:10.5194/acp-8-6939-2008, 2008

Kerminen, V. M., Anttila, T., Lehtinen, K. E. J., and Kulmala, M.: Parameterization for atmospheric new-particle formation: Application to a system involving sulfuric acid and condensable watersoluble organic vapors, Aerosol Sci. Tech., 38, 1001-1008, 2004.

Korhonen, H., Carslaw, K. S., Spracklen, D. V., Ridley, D. A., and Ström, J.: A global model study of processes controlling aerosol size distributions in the Arctic spring and summer, J. Geophys. Res., 113, 1-20, doi:10.1029/2007JD009114, 2008.

Kristiansen, N. I., Stohl, A., Olivié, D. J. L., Croft, B., Søvde, O. A., Klein, H., Christoudias, T., Kunkel, D., Leadbetter, S. J., Lee, Y. H., Zhang, K., Tsigaridis, K., Bergman, T., Evangeliou, N., Wang, H., Ma, P.-L., Easter, R. C., Rasch, P. J., Liu, X., Pitari, G., Di Genova, G., Zhao, S. Y., Balkanski, Y., Bauer, S. E., Faluvegi, G. S., Kokkola, H., Martin, R. V., Pierce, J. R., Schulz, M., Shindell, D., Tost, H., and Zhang, H.: Evaluation of observed and modelled aerosol lifetimes using radioactive tracers of opportunity and an ensemble of 19 global models, Atmos. Chem. Phys., 16, 3525-3561, doi:10.5194/acp-16-3525-2016, 2016.

Leaitch, W. R., Sharma, S., Huang, L., Toom-Sauntry, D., Chivulescu, A., Macdonald, A. M., von Salzen, K., Pierce, J.
R., Bertram, A. K., Schroder, J. C., Shantz, N. C., Chang, R. Y. W., and Norman, A.-L.: Dimethyl sulfide control of the clean summertime Arctic aerosol and cloud, Elem. Sci. Anth., 1, 17, doi:10.12952/journal.elementa.000017, 2013.

Leaitch, W. R., Korolev, A., Aliabadi, A. A., Burkart, J., Willis, M., Abbatt, J. P. D., Bozem, H., Hoor, P., Köllner, F., Schneider, J., Herber, A., Konrad, C., and Brauner, R.: Effects of 20-100 nanometre particles on liquid clouds in the clean summertime Arctic, Atmos. Chem. Phys. Discuss., doi:10.5194/acp-2015999, in review, 2016.

Lee, Y. H. and Adams, P. J.: A Fast and Efficient Version of the TwO-Moment Aerosol Sectional (TOMAS) Global Aerosol Microphysics Model, Aerosol Sci. Tech., 46, 678-689, doi:10.1080/02786826.2011.643259, 2012.

Lee, Y. H., Pierce, J. R., and Adams, P. J.: Representation of nucleation mode microphysics in a global aerosol model with sectional microphysics, Geosci. Model Dev., 6, 1221-1232, doi:10.5194/gmd-6-1221-2013, 2013.

Lee, L. A., Pringle, K. J., Reddington, C. L., Mann, G. W., Stier, P., Spracklen, D. V., Pierce, J. R., and Carslaw, K. S.: The magnitude and causes of uncertainty in global model simulations of cloud condensation nuclei, Atmos. Chem. Phys., 13, 8879-8914, doi:10.5194/acp-13-8879-2013, 2013.

Liu, H., Jacob, D. J., Bey, I., and Yantosca, R. M.: Constraints from ${ }^{210} \mathrm{~Pb}$ and ${ }^{7} \mathrm{Be}$ on wet deposition and transport in a global threedimensional chemical tracer model driven by assimilated meteorological fields, J. Geophys. Res., 106, 12109-12128, 2001.

Lohmann, U. and Feichter, J.: Global indirect aerosol effects: a review, Atmos. Chem. Phys., 5, 715-737, doi:10.5194/acp-5-7152005, 2005.

Mann, G. W., Carslaw, K. S., Spracklen, D. V., Ridley, D. A., Manktelow, P. T., Chipperfield, M. P., Pickering, S. J., and Johnson, C. E.: Description and evaluation of GLOMAP-mode: a modal global aerosol microphysics model for the UKCA composition-climate model, Geosci. Model Dev., 3, 519-551, doi:10.5194/gmd-3-519-2010, 2010.

Mann, G. W., Carslaw, K. S., Ridley, D. A., Spracklen, D. V., Pringle, K. J., Merikanto, J., Korhonen, H., Schwarz, J. P., Lee, L. A., Manktelow, P. T., Woodhouse, M. T., Schmidt, A., Breider, T. J., Emmerson, K. M., Reddington, C. L., Chipperfield, M. P., and Pickering, S. J.: Intercomparison of modal and sectional aerosol microphysics representations within the same 3-D global chemical transport model, Atmos. Chem. Phys., 12, 4449-4476, doi:10.5194/acp-12-4449-2012, 2012.

Möhler, O. and Arnold, F.: Gaseous sulfuric acid and sulfur dioxide measurements in the Arctic troposphere and lower stratosphere: Implications for hydroxyl radical abundances, Geophys. Res. Lett., 19, 1763-1766, 1992.

O'Dowd, C. D. and de Leeuw, G.: Marine aerosol production: a review of the current knowledge, Philos. T. R. Soc. A., 365, 17531774, doi:10.1098/rsta.2007.2043, 2007.

Olenius, T., Kupiainen-Määttä, O., Ortega, I. K., Kurtén, T., and Vehkamäki, H.: Free energy barrier in the growth of sulfuric acidammonia and sulfuric acid-dimethylamine clusters, J. Chem. Phys., 139, 084312, doi:10.1063/1.4819024, 2013.

Pierce, J. R. and Adams, P. J.: Uncertainty in global CCN concentrations from uncertain aerosol nucleation and primary emission rates, Atmos. Chem. Phys., 9, 1339-1356, doi:10.5194/acp-91339-2009, 2009. 
Pierce, J. R., Riipinen, I., Kulmala, M., Ehn, M., Petäjä, T., Junninen, H., Worsnop, D. R., and Donahue, N. M.: Quantification of the volatility of secondary organic compounds in ultrafine particles during nucleation events, Atmos. Chem. Phys., 11, 90199036, doi:10.5194/acp-11-9019-2011, 2011.

Pierce, J. R., Evans, M. J., Scott, C. E., D'Andrea, S. D., Farmer, D. K., Swietlicki, E., and Spracklen, D. V.: Weak global sensitivity of cloud condensation nuclei and the aerosol indirect effect to Criegee $+\mathrm{SO}_{2}$ chemistry, Atmos. Chem. Phys., 13, 3163-3176, doi:10.5194/acp-13-3163-2013, 2013.

Pierce, J. R., Croft, B., Kodros, J. K., D’Andrea, S. D., and Martin, R. V.: The importance of interstitial particle scavenging by cloud droplets in shaping the remote aerosol size distribution and global aerosol-climate effects, Atmos. Chem. Phys., 15, 61476158, doi:10.5194/acp-15-6147-2015, 2015.

Riddick, S. N., Dragosits, U., Blackall, T. D., Daunt, F., Wanless, S., and Sutton, M. A.: The global distribution of ammonia emissions from seabird colonies, Atmos. Environ., 55, 319-327, doi:10.1016/j.atmosenv.2012.02.052, 2012.

Riipinen, I., Pierce, J. R., Yli-Juuti, T., Nieminen, T., Häkkinen, S., Ehn, M., Junninen, H., Lehtipalo, K., Petäjä, T., Slowik, J., Chang, R., Shantz, N. C., Abbatt, J., Leaitch, W. R., Kerminen, V.-M., Worsnop, D. R., Pandis, S. N., Donahue, N. M., and Kulmala, M.: Organic condensation: a vital link connecting aerosol formation to cloud condensation nuclei $(\mathrm{CCN})$ concentrations, Atmos. Chem. Phys., 11, 3865-3878, doi:10.5194/acp-11-38652011, 2011.

Seabird Information Network: Circumpolar Seabird Data Portal, available at: http://axiom.seabirds.net/circumpolar_portal. php (last access: 13 March 2015), 2015.

Sharma, S., Ishizawa, M., Chan, D., Lavoué, D., Andrews, E., Eleftheriadis, K., and Maksyutov, S.: 16-year simulation of Arctic black carbon: Transport, source contribution, and sensitivity analysis on deposition, J. Geophys. Res.-Atmos., 118, 943-964, doi:10.1029/2012JD017774, 2013.

Shindell, D. and Faluvegi, G.: Climate response to regional radiative forcing during the twentieth century, Nat. Geosci., 2, 294-300, doi:10.1038/NGEO473, 2009.

Shupe, M. D., Uttal, T., Matrosov, S. Y., and Frisch, A. S.: Cloud Water Contents and Hydrometeor Sizes During the FIRE Arctic Clouds Experiment, J. Geophys. Res., 106, 15015-15028, 2001.

Spracklen, D. V., Pringle, K. J., Carslaw, K. S., Chipperfield, M. P., and Mann, G. W.: A global off-line model of sizeresolved aerosol microphysics: I. Model development and prediction of aerosol properties, Atmos. Chem. Phys., 5, 22272252, doi:10.5194/acp-5-2227-2005, 2005a.

Spracklen, D. V., Pringle, K. J., Carslaw, K. S., Chipperfield, M. P., and Mann, G. W.: A global off-line model of size-resolved aerosol microphysics: II. Identification of key uncertainties, Atmos. Chem. Phys., 5, 3233-3250, doi:10.5194/acp-5-3233-2005, 2005b.

Spracklen, D. V., Carslaw, K. S., Kulmala, M., Kerminen, V. M., Sihto, S. L., Riipinen, I., Merikanto, J., Mann, G. W., Chipperfield, M. P., Wiedensohler, A., Birmili, W., and Lihavainen, H.: Contribution of particle formation to global cloud condensation nuclei concentrations, Geophys. Res. Lett., 35, D06808, doi:10.1029/2007GL033038, 2008.

Stevens, R. G. and Pierce, J. R.: The contribution of plume-scale nucleation to global and regional aerosol and $\mathrm{CCN}$ concentrations: evaluation and sensitivity to emissions changes, Atmos. Chem. Phys., 14, 13661-13679, doi:10.5194/acp-14-13661-2014, 2014.

Stohl, A., Klimont, Z., Eckhardt, S., Kupiainen, K., Shevchenko, V. P., Kopeikin, V. M., and Novigatsky, A. N.: Black carbon in the Arctic: the underestimated role of gas flaring and residential combustion emissions, Atmos. Chem. Phys., 13, 8833-8855, doi:10.5194/acp-13-8833-2013, 2013.

Ström, J., Umegard, J., Torseth, K., Tunved, P., Hansson, H. C., Holmen, K., Wismann, V., Herber, A., and Konig-Langlo, G.: One year of particle size distribution and aerosol chemical composition measurements at the Zeppelin Station, Svalbard, March 2000-March 2001, Phys. Chem. Earth, 28, 1181-1190, doi:10.1016/j.pce.2003.08.058, 2003.

Trivitayanurak, W., Adams, P. J., Spracklen, D. V., and Carslaw, K. S.: Tropospheric aerosol microphysics simulation with assimilated meteorology: model description and intermodel comparison, Atmos. Chem. Phys., 8, 3149-3168, doi:10.5194/acp-83149-2008, 2008.

Tunved, P., Ström, J., and Krejci, R.: Arctic aerosol life cycle: linking aerosol size distributions observed between 2000 and 2010 with air mass transport and precipitation at Zeppelin station, Ny-Ålesund, Svalbard, Atmos. Chem. Phys., 13, 3643-3660, doi:10.5194/acp-13-3643-2013, 2013.

Twomey, S.: Pollution and the Planetary Albedo, Atmos. Environ., 8, 1251-1256, 1974.

Verheggen, B., Cozic, J., Weingartner, E., Bower, K., Mertes, S., Connolly, P., Gallagher, M., Flynn, M., Choularton, T., and Baltensperger, U.: Aerosol partitioning between the interstitial and the condensed phase in mixed-phase clouds, J. Geophys. Res., 112, D23202, doi:10.1029/2007JD008714, 2007.

Wang, M. and Penner, J. E.: Aerosol indirect forcing in a global model with particle nucleation, Atmos. Chem. Phys., 9, 239-260, doi:10.5194/acp-9-239-2009, 2009.

Wang, Q., Jacob, D. J., Fisher, J. A., Mao, J., Leibensperger, E. M., Carouge, C. C., Le Sager, P., Kondo, Y., Jimenez, J. L., Cubison, M. J., and Doherty, S. J.: Sources of carbonaceous aerosols and deposited black carbon in the Arctic in winter-spring: implications for radiative forcing, Atmos. Chem. Phys., 11, 1245312473, doi:10.5194/acp-11-12453-2011, 2011.

Wentworth, G. R., Murphy, J. G., Croft, B., Martin, R. V., Pierce, J. R., Côté, J.-S., Courchesne, I., Tremblay, J.-É., Gagnon, J., Thomas, J. L., Sharma, S., Toom-Sauntry, D., Chivulescu, A., Levasseur, M., and Abbatt, J. P. D.: Ammonia in the summertime Arctic marine boundary layer: sources, sinks, and implications, Atmos. Chem. Phys., 16, 1937-1953, doi:10.5194/acp-16-19372016, 2016.

Wesely, M. L.: Parameterization of surface resistances to gaseous dry deposition in regional-scale numerical models, Atmos. Environ., 23, 1293-1304, 1989.

Yu, F.: A secondary organic aerosol formation model considering successive oxidation aging and kinetic condensation of organic compounds: global scale implications, Atmos. Chem. Phys., 11, 1083-1099, doi:10.5194/acp-11-1083-2011, 2011.

Yu, F. and Luo, G.: Simulation of particle size distribution with a global aerosol model: contribution of nucleation to aerosol and CCN number concentrations, Atmos. Chem. Phys., 9, 76917710, doi:10.5194/acp-9-7691-2009, 2009. 